Historic, Archive Document

Do not assume content reflects current scientific knowledge, policies, or practices. 

A93.6

P.9

cro. 2

SERIES I. EVALUATION OF FOREIGN FRUITS AND NUTS.

№. 5. APRICOTS.

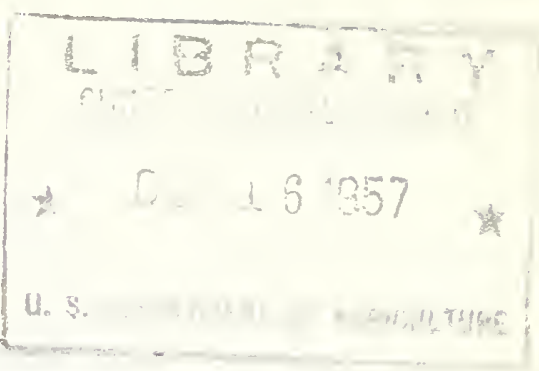

APRICOT VARIETIES TESTED AT CHICO, CAIIFORNIA

BY

LIOYD E. JOLEY

U. S. Plant Introduction Garden, Chico, California

Horticultural Crops Research Branch, Agricultural Research Service

U. S. Department of Agriculture

This report is prepared as a cooperative service to state and federal experiment stations and presents evaluation data taken at the Chico Plant Introduction Garden. Varietal names listed are those under which the material was introduced.

April 1956 

Apricot Varieties Tested at Chico. California

by Iloyd E. Joley, U. S. Plant Introcuction

Garden, Chico, California

First Report

1. BLANC ROSE I CONFIRE

Prinus armeniaca

Iiterature and Miscellaneous Notes

Catalog Descriptiv des Fruits Adoptes, 1927, p. 506. Blane Rose. Listed under regicnal varieties. Synonyms: Poman rose, Porman rose, Blanc Pomman rose. Fruit medium size, elongated, conic oval, well compressed on the cheeks. Back with a keel someishat curved, ventral suture more curving. Pale yellow skin with pinkish-purple, crimson in the sun. Fit flat, elongated. Seed is sweet. Flesh pale yellow, fine, freestone: fiavor pronounced and agreeable. Quality good. Late June and July. This variety produces abundantly along the Mediterranean and in Auvergne. Comprerciai expcrt variety and much used for cooking.

Bartre: I'Abricotier en Rousillon. Pomologie Francaise 1932 No.2. pp. 43-47. Blane rose is the best apricot for confiseries: is grown siccessfully on plateaus of Caromb and of Loriol and in alluvions of Cabanises, Orgon, ete. There trees develop well, are erect and yield overo 300 kilos each. Price of this variety always double those of other varieties.

Bliu, Henry: Les varieties fruitieres a cultiver pour I'exportation. Rev. hort. 80: 128-130。 1908. Blane rose d'Confire is the third on list of 8 varieties recon unded as suitable for export. Handsome fruit, highly valued by the Eriglish, who use it much in the manufacture of pulp: inedium size. Tree easy to grow.

Catalog of Lejba, Spain, about 1934. Rose Pomar. Whitish pink. Large elongated, juicy, aromatic. June.

Catalog of Negree, France, 1933. Blane rose or Pommant. June-July. Used for shipment and particulariy for cooking.

Catalog of Orero, Spain, about 1934. Blane Poman Rose. Rather large, flattened; flesh firm and perfumed, valued for cooking. (On general rather than comercial list).

Listed by 2 of 26 French catalogs examined 2/27/42. Listed by 1 of 1 Swiss catalog examined 2/27/42. Not listed by 2 Belgian catalogs examined 2/27/42.

*Horticulturist in Charge. 

Evaluation Data

U. S. Plant Introduction Garden, Chico, California

P. I. 101841. Blane rose a Confire. Trees received from Brayard, Morocco, 2/2/33. Fruit picked at Chico 7/7/37: season $7 / 5$ to $7 / 13$. Size uniform about 2 inches in length, 1.8 inches in diameter and $2 \mathrm{oz}$. in weight. Shape regular, roundish; halves unequal: cavity deep, wide, abrupt; suture shallow but distinct; apex slightly depressed; skin color greenish: pubescence short and light; dots obscure; skin thin but tough, adherent to the flesh: flesh color white, evenly distriouted; mediun juice; texture coarse; stone rree, large $11 / 8$ in. long by $7 / 8$ in. in dianeter, ovate, plump, blunt, slightIy pitted; flavor flat; quality poor. Darkens and rots around pit cavity. Fruit of no value: on a 1 to 10 rating this variety rates 1 or very poor.

2. BIANC

Prunus arme:ziaca.

\section{Literature and Miscellaneous Notes}

The name of this variety suggests a possible relationship to Blane rose à Coufire. However, from a comparison of fruit outline and description given in Catalog Descriptîv, 1927, for Blanc rose à Confire with those made at Chico for P.I. 101841 and 121562, it appears doubtful that either introduction is the variety as described in Catalog Descriptiv.

Evaluation Data

U. S. Plant Introduction Garden, Chico, California

P.I. 121562. BIanc. Trees received from H. Brayard, Marrakech, Morocco. 3/5/37. Fruit picked at Chico 6/12/46; season 6/10-6/17; skin color an attractive yellow with red blush and slight green mottle; flesh color deep jellow, slightly orange yellow: flavor mild: sweet, tends to be flat: quali.ty poor to fair: stone free. Rather attractive external appearance. Time of ful hloom $3 / 10 / 42,3 / 8 / 46$ and $3 / 20 / 49$ : Blenheim $3 / 12 / 46$ and $3 / 15 / 49:$ Tis ton $3 / 13 / 46$ and $3 / 18 / 49$ 。

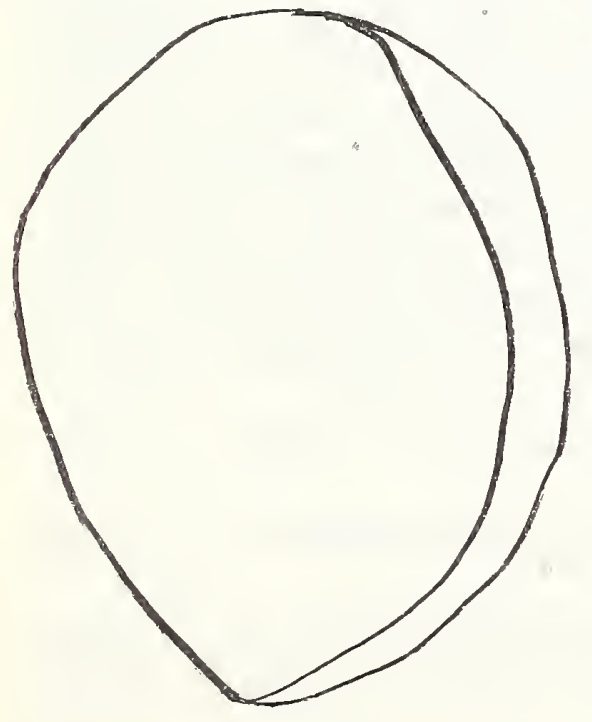

Blane rose à Confire

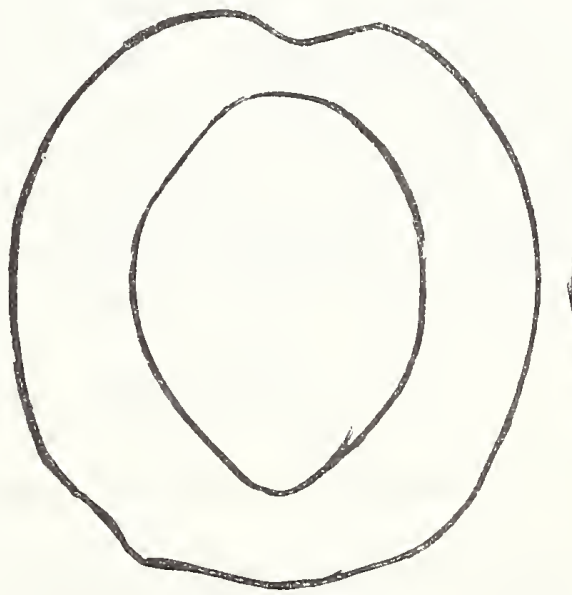

P.I.10184I

Blane rose à Confire

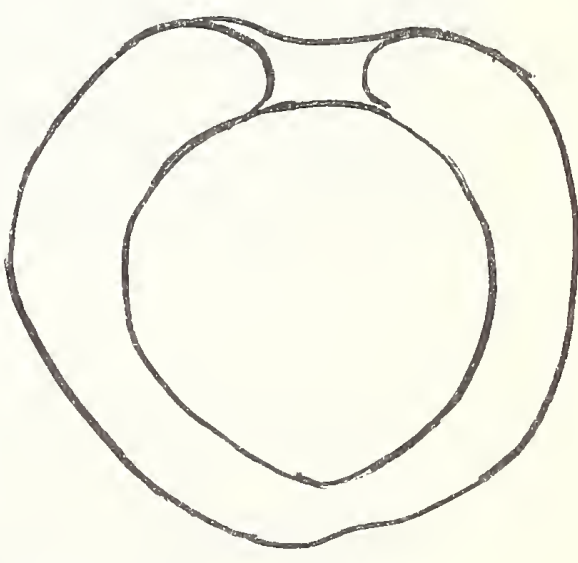

P.I.I21562

Blanc 


\section{Evaluation Data \\ U. S. Plant Introduction Garden, Chico, California}

P.I. 73455. Boulbon. Plants received from Juan Leyve Granada, Spain, ApriI 1927. Fruit picked at Chico 6/13/39 with a season of 6/11-17/39. Hangs fairly well. Average length $4.2 \mathrm{~cm}$. diameter $4.1 \mathrm{~cm}$, and weight 34.5 gms. Shape regular, roundish ovate, halves slightly unequal. Cavity medium deen, wide, regular, flaring, Suture shallow. distinct. Apex roundish Skin:color light yellow with up to 10 to 20 percent red blush: medium thickness and toughness; adherent to flesin: pubescence light. Stem medium thick, $0.6 \mathrm{~cm}$. long. Flesh: color creamy white, juicy; texture slightly stringy, tender, melting: flavor sweet, mild; quality fair. Stone free, mediuin size, oval, blunt, lightly pitted, brom.

Time of full bloom: $3 / 12 / 48,3 / 20 / 49,3 / 6 / 50,3 / 20 / 51$ and $3 / 15 / 53$, averaging 3/14-15 for these years: for Blenheim 3/11 and Tilton 3/12 during these years.

\section{Comments}

1935-39. Rated 1 of a possible 10 score for this period. Fair quality: sunburns; darkens at pit; pale color; no commercial value.

Because of differences in time of bloom and color of fruit it appears that this is not the same as Precoce de Boulbon (P.I. 65995). Outline of this fruit recorded under description of Precoce de Boulbon.

4. BULLIDA

Prunus armeniaca

\section{Literature and Miscellaneous Notes}

Catalog of Orero $\$ 40$, Spain, about 1934. Bulida. The best of the early apricots, which should not be lacking in any commercial planting. Tree of great size and heavy production. Fruit of average size and weighing on the average $55 \mathrm{gms}$. Yellow, with bright red and croimson in the sin. Flesh very firm and aromatic, of good color and freestone. Combines conditions special for making preserves and also for drying. Season from the first of June and in warm countries the midole of May, and as it has resistance for shipment, it finds ready sale。

Not in Lebya's Catalog, Spain, about 1934.

Catalog of Rociolansse, France, 1938-9. Bulida. Ripens late July.

Catalog of San Juan, Spain, \#29 (about 1934). Bulida. Froit large, flesh firm and good, excellent for commercial plantings: late Jurse. 
Evaluation Data

\section{U. S. Plant Introduction Garden, Crico, Calirorriza}

P.I. 91452. Bullida. Cuttings received from C. Bey Rozet, Direction Generale de e Agriculture, Morocco, through H. Brayara, Directeur de la Ferme Fromerimentale, Marrakech, Morocco, Jamuary 1931. Fruit picked $6 / 7 / 37,6 / 23 / 38,5 / 29 / 40$ and $6 / 3 / 41$ with seasons of $6 / 18-25 / 38$ and $5 / 27-6 / 8 / 40$. Fruit drops rather readily some years but hangs well others. Size generally uniform but occasionally variable, averaging 5.0 cm. in length, $5.1 \mathrm{~cm}$. in diameter and $62.7 \mathrm{gms}$. in weight with ranges for different years of 4.7 to $5.3 \mathrm{~cm}$. for length, $4.6-5.6 \mathrm{~cm}$. for diameter and 42.5 to 77.4 gms for weight. Shape fairly uniform, roundish to cordate cvate and oblate, halves unequal. Carity medium depth, medium wide to wide, variable flaring to abrupt but usually cut by suture. Suture lips unequal, a distinet line but varoable depth, sometimes deep at base and shallow at apex. Apex roundish. lightiy depressed. Pistillary point a scar. Skin: color yellow to orange-yellow, blushed red where exposed to sun. Iively; medium thick; medium tough to tough: adherent to the flesh: pubescence short and light; bioom light: dots feri, small, incorspicuous, the few that color are purplish red. Flesh: color variable, pale yellow through orange yellow for the different years: juice moderate, mostly pale yellow: texture fine grained, firm, crisp but tender, juicy, sometimes mealy, melting. Flaror somewhat variable, sometimes subacid, almost tart, at other times somewhat flat, almost insipid, slightly sweet, generally mild: quality fair. Stone free, large, oval to ovate, plump, blunt, surface pitted, brown, suture winged. Kernel bitter.

Time of full bloom $3 \cdot 12 / 37,3 / 20 / 38$ and $3 / 17 / 39:$ average 3/16-17. No comparable dates available for Blenheim and Tilton but for period 1942 and 1946 to 1953, their average was 3/10-11 and 3/13-14, respectively.

\section{Comments}

1937. Attractive appearance but lacking 2 n sugar and flavor. Pit and carity too large. No value for fruit. 1938. Less desirable than other varieties ripening at tinis same time. 1939. For the period 1935-39 BuIlida (P.I.91457) was rated and scored 3 of a possible 10; Di, Breda scored 8. Trevatt 7. Fair size, good color. attractive but lacking in sugar and flavor. Pit and cavity large. of doubtful value. 1940. Crop light, hangs well, early。 Large seed. Lacks sugar。 Rather late going dormant. 1942. Rough surface due to a heavy surface rot causing a darkened, sunken, irregular appearance at or near the apex. Medium yield, scattered bearing habit. Verg large, vigorous tree. light shot hole infection.

Of 88 seedlings and varieties rated and scored in 1941 this introduction of Bullida (P.I. 91457) was 87 on the list with score of 53 of a possible 150 . broken down as follows: Keeping quality 5/40, attractiveness 5/10. flavor 10/20, size 8/10, color 4/10, quality 5/10, seed size and cavity 5/10. disease of fruit $1 / 10$ and freestone 10/10.

This introduction earmarked for discard because of its adverse qualities. 

P.I. 101842. Buliida. Plants received from. Brayard, Directeru de la Ferne Experimentale, Marrakech, Morocoo. January 1933. At Chico this does not appear to be the sane as P.I. 91457 . Frust picked $6 / 22 / 39$ and $6 / 4 / 40$ with seasons of 6/14-20/39 and 6/2010/40. Fruit drops iatrer readily, Size variable in 1939 but foirly uniform in 1940 with average lengths of $4.5 \mathrm{~cm}$. and $4.7 \mathrm{~cm}$. diameters of $4.6 \mathrm{~cm}$ and $5.3 \mathrm{~cm}$. and weights of $49.2 \mathrm{gms}$. and $63.5 \mathrm{gms}$. for each jear. Shape regular, roundish oblate, halves nearly equal to unequal. Cavity medium depth and tidth regular: medium abrupt to rlaring; cut by suture. Suture lips unequal: changing depth shaliow to medium but mostly medium: distinct. Apex flattened, some lightly depressed. Pistillary point a scar. Skin: color greenish yeliov to Jellow few lightIy blushed, dull; medium thickness and toughress; adherent to flesh: pubescence light; no bloom: dots inconspicuous. Ster medium thickness. $.6 \mathrm{~cm}$. long. Flesh: color greenish JeIlow to yellow avenly distributed: moderate pale yellew juice: texture medium fine grainea tender, jujey melting: flavor subacid, mild: quality fair and fair to pooro stone free. medium size; oval, piump, blunt: suriace rough, pitted, light brown: suture winged。

\section{Cominests}

1939. Doubtful value. Sortens and darkens at the pit. This introduction of Bullida (F.I.101842) scored 2 of a possibie 10 in the 1935039 rating as compared to P.I. 9145\%. Size good, color fair but only fair quality and it softens and darkens at the pit. Doubtful value.

1940. Lacks sugar and attractive appearance. Darkers at pit. Does not appear to be the same as BuIiida P.I. $9145 \%$.
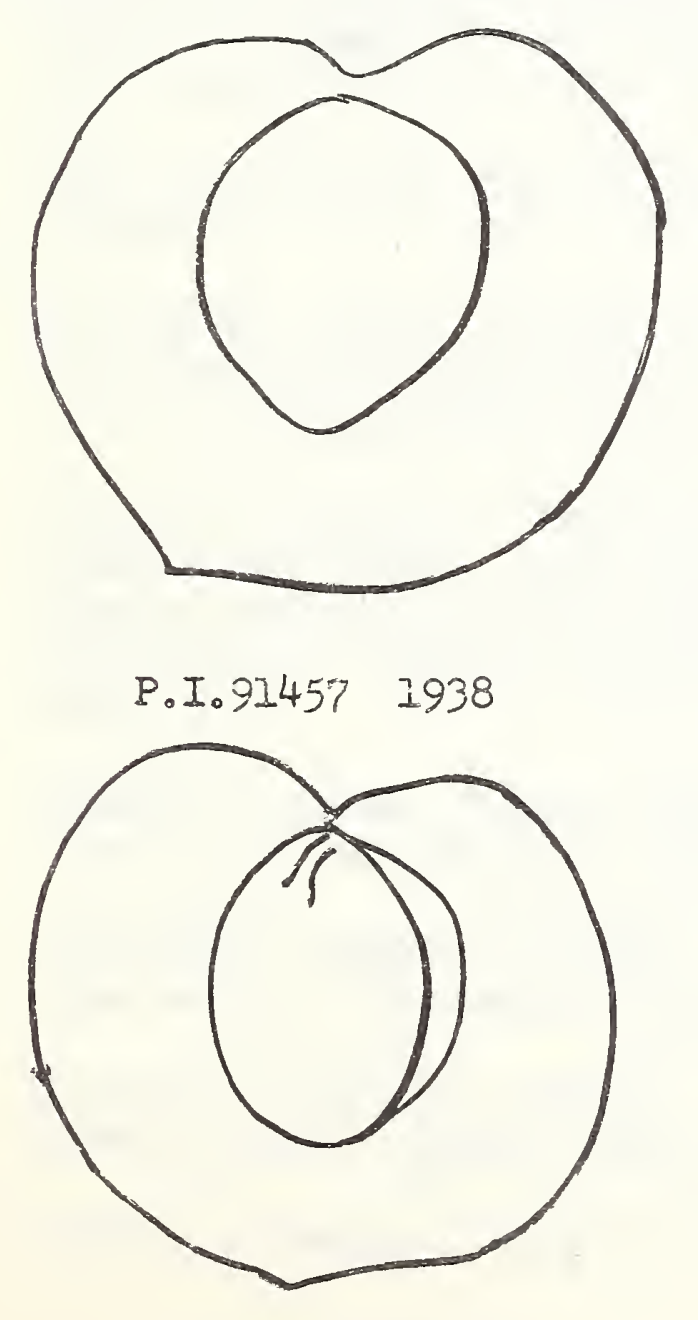

P.I.101842 1939

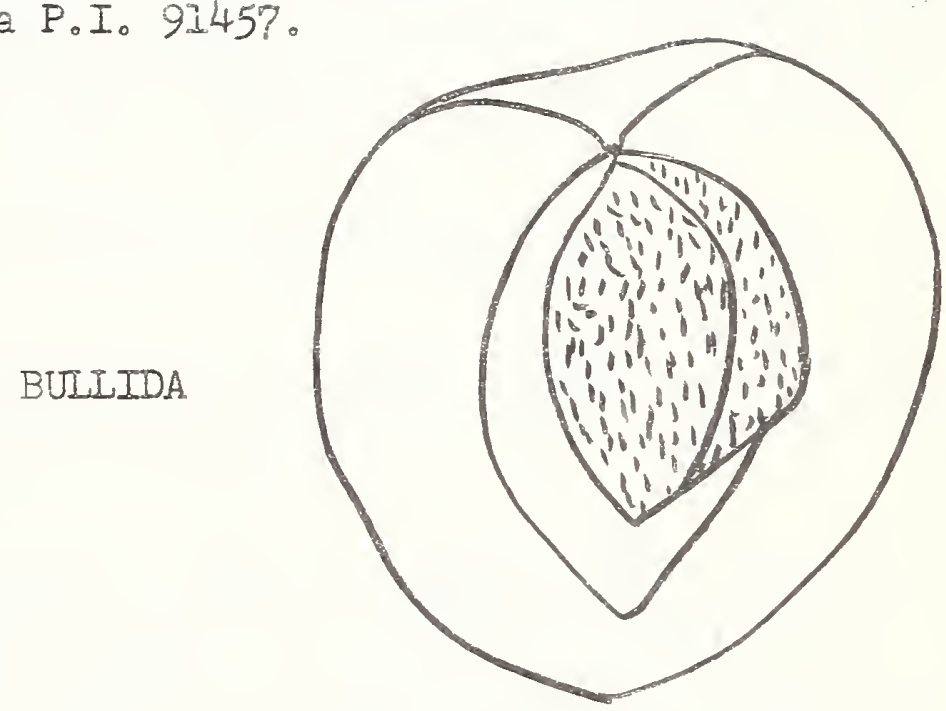

$P .509245$ ? 1941

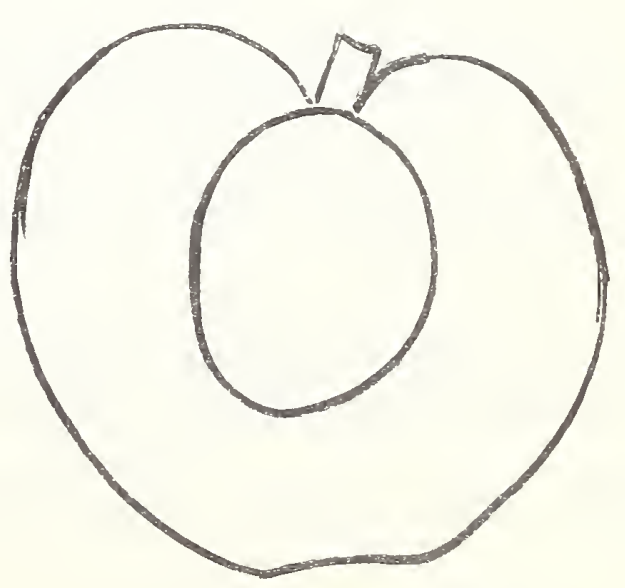

P. T.201842 2940 


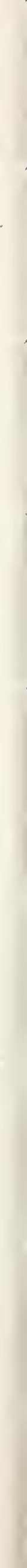




\section{Literature and Miscellaneous Notes}

Catalog Descriptiv des Fruits Adoptes, 1927, p.18, Cormun. Synonyms: Abricot Crotte; Conice de Toulon; Gros Abricet ordinaire: Roman; Trans parent: Turkey. Fruit fairly large, origin very ancient。 Rounded., appearing generally oval. Suture thick, short. Cavity deep and irregula ${ }^{\circ}$. Skin thick, deep yellow, washed with vermillion; blood, red in the sun, often with small brown protuberant spots. Flesh amber yellow, halffine, melting, juicy, sweet, aroma fine and delicate, Quality very good. Kernel bitter. July. Recommended much for cooking, especially when grom as tall standard.

Bunyard, Handbook of Hardy Fruits, 1925. Common F.. Cormun。: (Brussels, Roman) Medium, early August, oblong-cval, a little flat sided with a narrow and deep suture, of which one sicle is larger。 Colour, rather pale yeliow to orange yellow on sunny side, which has dots or splashes of red brown. Flesh pale yellow, of inferior flavor. Stone oblong, rather flat, Lecives, rather small, roundish oval. Growth slender。Fertility, fair。 Origin, a very old variety, which may go back to Roman times. Not now worth growing.

Thomas, American Fruit Culturist, 1885. Roman (Abricot Commun). Medium in size, rather oval, compressed, suture small or obscure: surface pale yellow, with a few red dots to the sun: flesh very fine grained, half juicy, with a mild pleasant flavor. Kernel bitter. Worthless in England but greatly improved by our warm summers. Productive. Season rather early, or medium, or two weeks after midsumer. It is disseminated in this country under various erroneous names.

The blotch-leaved Roman differs only in the yellow spot or stain of its leaves.

Catalog of Bernay, France, 1938-39. Gros Comman. Frưt large, flesh fine, for cooking and syrup. Late July, early August (of the 3 groups arranged in order of ripening this is in the thirod).

Catalog of Bianchi, Italy, 1932-33. Commune (Romano: Gros ordinaire)。 Fruit rather large, irregularly globose; skin thick, lightly dow. whitish yellow in shadé, golden yellow in sun and covered with brown and russet dots. Flesh a handsome yellow: meltirg: freestoni. First quality. Mid-July。

Catalog of Crovx, France, 1938-39. Commun. Frizt fairly large, good or fairly good according to the nature of the soil. Early August.

Catalog of Giannini, Italy, 1933-34. Commune. Fruit fairly large, almost spherical; of the best. JuIy.

Catalog of Lecolier, France, 1938. Commun (Gros Commun, Crotte, gaviex)。 Blossoms late。Fruit fairly large, yellow with crimson, duroing July。

Catalog of Negree, France, 1933. Comice de Toulon, June, July, Good. 
Catalog of Raverdam, France, 1932-33. Commun. Fruit fairly large, quality very good, tree vigorous and productive second half July.

Listed by 7 of 26 French catalogs examined $2 / 27 / 42$ as Commun. Listed by 1 of 26 French catalogs examined 2/27/42 as Gros Commur. Iisted by 1 of 26 French catalogs examined 2/2\%/42 as Comice de Toulon. Not listed by 1 Swiss and 2 Belgian catalogs examined 2/27/42。 Listed by 2 of 7 Italian catalogs examined $3 / 2 / 42$.

\section{Evaluation Data}

\section{U. S. Plant Introduction Garden, Chico, California}

F 202562. Commune (Commun)。 Plants received from G. Giannini, Stabilimento douricoltura, Pistoia. Italy, April 1933. Frait picked at Chico, 6/30/38 and $6 / 15 / 39$ with seasons of $6 / 24-7 / 2 / 38$ and $6 / 13020 / 39$. Hangs fairly well. Size quite uniform wh average length of $4.1 \mathrm{~cm}$, diameter $4.3 \mathrm{~cm} .0$ and weight 38.6 gms. ranges are $4.0-4.2 \mathrm{~cm}$. for length, 4.0 .4 .6 cr for diameter and 37.3 to $40.0 \mathrm{gms}$. for weight. chape roundish oblate, halves unequal. Carity medium to medium deep, mostly medium wide, rather abrupt, ridged. cut deeply by suture. Suture medium in 1938, shallow in 1939, distinct. Apex variable, some rounded but others flattened, slightly depressed. Skin color dull creamy to pale yellow, lightly blushed, thin to medium thick. medium tough, slightly astringent, adherent to flesh, pubescence short, very fine, dots inconspicuous, stem thick, $.5 \mathrm{~cm}$. long. Flesh color creamy white to pale yellow, Iighter at pit, otherwise ever distribution, moderate juice, texture fine grain, some stringiness, tender, melting: flavor sweet, subacid, mild; quality fair to poor. Stone free, medium size, roundish-oval, plump, blunt, surface pitted, brown.

Comments: 1938. Poor color. 1939. Darkens at pit. No commercial value.

For the period 1935-39 Commune (P.I.102562) rated 1 out of a possible 10 score with Di Breda, Trevatt and Pesca di Nancy scoring 8, 7 and 6. zospectively. Poor color, darkens at pit, stringy, semiocling.

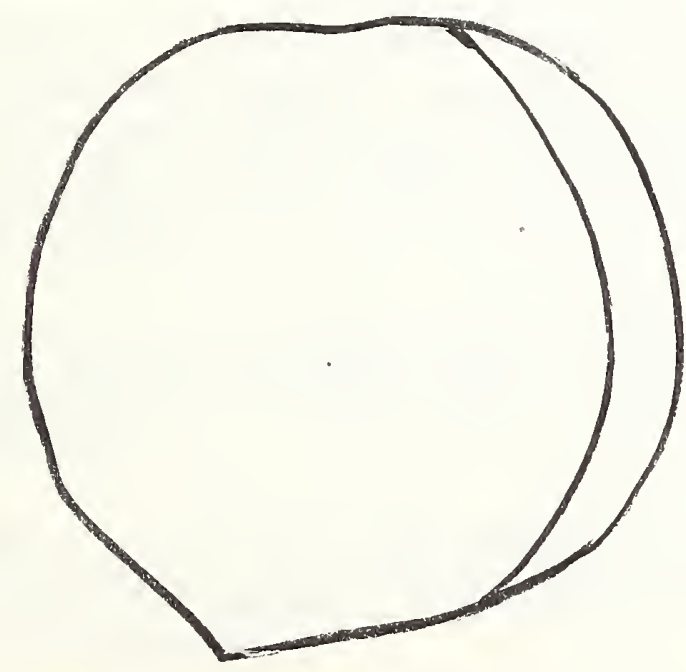

From Catalog Descroiptiv 1927

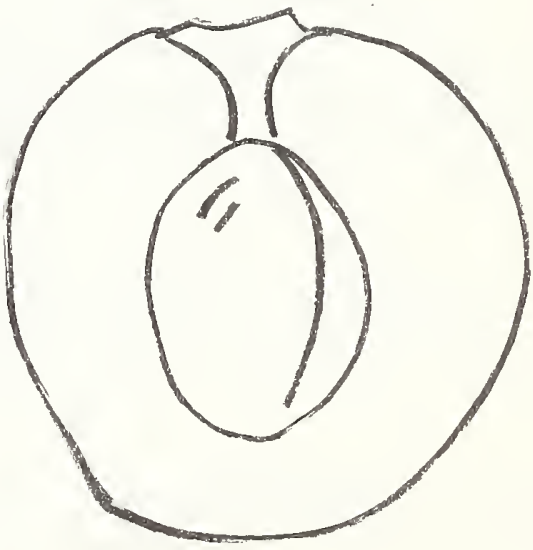

P. T. 102562

Commuss 


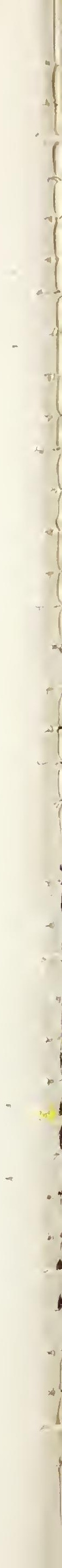


6. DI BREDA

Prunus ameniaca

\section{Iiterature and Miscellaneous Notes}

Bunyard, Handbook of Hardy Fruits, 1925. Breda, Iind. Porn。Brit, III. I46 F。 Aveline (Hollande). Medium, mid-August, round, flattened each end, often a little compressed on the sides, suture rather deep. Color rich orange with a dark brownish red flush. Flesh orange, tender, falirly good and sweet. Stone free, round, kemel sweet, Growth moderate, very fertile. Leaves roundish oval, really more spear head shaped, finely pointed, serrate. Origin- according to Miller this came originaliy from Africa (through Tradescant ? ) but imported into England from Breda. Hogg thinks our Breda cannot be this as Miller described it as large。 It has, however. large in Miller's day compared with the other varieties then cultivated. A hardy variety, fmiting occasionally as a standard in warm situations.

Hogg。 Fruit Manual, 1884. Listed as Breda.

Thomas, American Fruit Culturist, 1885. Breda (Holland, Amande Aveline)。 Rather small, sometimes nearly medium (an inch and a half diameter). roundish, obscurely four sided, suture distinet. Surface orange with a dark reddish orange cheek. Flesh deep orange, free from the stone, rich and highly flavored. Sweet kernel. Quite early, or a week or two after midsumer. Hardy for an apricot and very productive.

Catalog of Bobeth, Germany, 1938-39. Von Breda. Ripens early to middle to end of August. Very fine pineapple-like flavor. One of the best liked varieties.

Catalog of Böttcher and Bergfeld, Germanv, 1936-37. Breda-Aprikose。 Fruit medium size, dark yellow with some red。 Flesh yellow, soft, pireapple spiced. Tree medium sized, very fruitful. Early to mideAugust.

Catalog of Fruit Trees, Bunyard and Company, England, 1938-39. Breda. Medium, midaAugust, roundish, rich orange with brownish-red flush. Flesh tender and sweet. One of the hardiest and best cropping varieties which has been grown in this country for several centuries. (Grown as Maidens and Fans).

Ca.talog of J. Cheal \& Snne Fngland, 1938. Breda. End of August. Small, rich flavor. Very hardy (Sold as dwarf fan trained, larger trees and maidens)。

Catalog of Dahs \& Nevenfels, Germany, 1939-40. Breda aprikose. Highly valued for table and conserve. Trees of moderate vigor, not susceptible and productive. 

Catalog of Goos \& Koenemann. Germany, 1938-39. Aprikose von Breaca. Medium size yellow with red, fire pineapple-iike flavor, early to rildale of August.

Catalog of Hillier \& Sons, England, 1937. Breda. Small, roundisb, orange mottled red, flesh orange. flavor fairly good, very hardy and prolifio. Used a.s standard in open ground in warm localities. Miz-August.

Catalog of Laxtor Bros., England, 1938. Breda. Middle of August. Medivn size, roundish, good rlavor, freestone.

Catalog of Schloesser, Germany, 1938-9. Vor Breda. Very fine for manufaco turoing.

Cataiog of Schmidtz-Hubsch, Germany, 1939-40. Aprikose aus Breda. Grourd color orange yellow, marbled dark, flesh vellowish, good market varoety. Eariy to past middle August. Fruit round, medium size, table, freestone. Iikes noist and rich soil, protected location. Blossoms tender to frost.

Catalog of Schwintzer, Italy, 1937-38. Di Breda. July. Medium size, yellow, dull red, perfumed. Tree hardy and very productive.

Catalog of Sgaravatti, Italy, 1932-33. Di Breda, Medium, pale, dull yellow, bright red, kernel sweet。 July.

Catalcg of Spooner \& Sons, Hounslow, Fngland, 1916-1?. Season early. Medium size, highly flavored. A very hardy kind, it may be grown as a standard.

Listed by 19 of 33 German catalogs examined 2/11/42.

Iisted by 7 of 15 English catalogs examined 2/25/42。

\section{Evaluatior Data \\ U. S. Plant Introduction Garden, Chico, California}

P.I. 65984. Di Breda. Trees received from Fratelli Sgaravatti, Saonara, Padova, Italy, 1926。 Fruit picked at Chico, 6/27/33,6/16/34, 6/13/39, $6 / 18 / 40$ and $6 / 20 / 41$ with seasons of $6 / 10-16 / 39,6 / 18-22 / 40$ and $6 / 18-26 / 41$. respectively. Fruit hangs well. Size fairly uniform, $4.9 \mathrm{~cm}$ in lergth. $4.8 \mathrm{~cm}$. in diameter and $55.1 \mathrm{gms}$. in weight. Shape uniform, regular, ovatecordate, compressed opposite suture, halves unequal. Cavity medium depth, wide, flaring, cut by suture. Suture lips unequal, shallow distinct, half circumference of fruit. Apex roundjsh. Pistiliary point a scar. Skin color greenish orange-yellow, uniform, some blush, dull, medium thick 


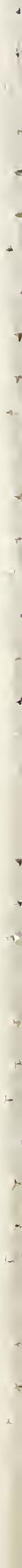


ress and tough.. 5s, adherent to flesh, pubescence light, dots few, small, varying froi. incansicuous to reddish brows. Flesh color deep yeliow to yellow-orange throughout, juice moderate, pale yellow, texture medium to coarse, tender but firm, juicy, melting. Flevor subacid, variable sweetness, some mild, aromatic. Quality good in 1939, fair to good in 1940 and fair in 1941. Stone free, medium to large, mostly cval to oval. ovate, plump, blunt, surface mostly pitted but some smootr, brom in color, suture winged.

Time of full bloom: $3 / 15 / 38,3 / 18 / 39,3 / 9 / 42,3 / 14 / 48,3 / 20 / 49,3 / 28 / 51$, $3 / 27 / 52$ and $3 / 27 / 53$. Average date of full bloom for ald years is March 19. Average date for Blenheim and Tilton during these same years, March 1.1 .

\section{Comments}

1932. An apricot of fine size and colcr. Quality good to very good. for canning and drying.

1933. Excellent quality. Has quality, size, color, even size ard shape, smooth around seed cavity.

1934. Very good to excellent, for canning and drying.

1939. A very good cot except for slight stringiness of flesh. A few days earlier than Blenheim or Tilton.

1940. Seems to withstand heat quite well. Good color and qualitw. 1941. Good size and flesh color. Flavor fair but not the best, lacking volume and sweetness. Fair external color. Tree large, spreading type. With a score of 113 of a possible 150, this variety rated 13th among 90 apricot seedlings and varieties rated on July 6, 1941. This score was broken down as follows: keeping quality 35/40, attractiveness 22/30, flavor 10/20, size 9/10, color 5/10, quality of flesh 6/10, seed size and cavity 7/10, disease of fruit 9/10 and freestone 10/10. Trevatt rated 129 and Pesca di Nancy 119. Blenheim and Tilton were not rated. Kernel of Di Breda (P.I. 65984) is sweet.

Amosg apricots fruiting at Chico from 1935 to 1939 this variety rated thiod after Real Fino (P.I. 102854) and Paviot (P.I. 65992) for commercial potentialities with a rating of 8 in a possible 10. Good quality. size and color. firm, few days earlier than Blenheim or Tilton. For canning, shipping or drying. Siight stringiness in flesh. Trevatt had a score of 7 and Pesca di Nancy 6 in this rating.

This introduction appears to agree rather well with the published description. 



\section{Iiterature and Miscellanoous Notes}

Catalog Descriptiv des Fruits Adoptes, 1927, p.23。 Docteur Niasclo. Raised in 1886 by Pelissier, nurseryman at Chateau-renard (Bouches du Rhone). Fruit very large, cheeks flattened, suture accentuated and compressed as far as the tip. Iips a little protuding. Cavity deep and narrow. Skin yellow, with lively orangerred, sometimes dotted with crimson in the sun. Flesh lively orange-yellow, fine, juicy, sweet perfumed, leaving a large cavity around the pit. Quality very good. Kemel bitter. Mid-July. This variety one of the earliest on our markets. Should be grown in southern slope where it gives the best results. It will be necessary to thin out the interior of the tree to avc a internal confusion. facilitate coloration and increase the perfume of the fruts.

Garnier, Max. Abricot "Docteur Mascle" Revohort.82: 156-157.1910。 First appearance Soc. Pom. de France was in form of a conserve. In October 1900. Pelissier, fruit grower at Chateaurenard (Bouches-du-Rhone) sent conserves of three varieties. Dr. Mascle. Blane rose and Gros muscat rou de Provence. First considered best. Fresh fruit described in 1907 as large, handsome, yellow, lightly washed with vermillion in the sun. Fruit has a fine flesh. jellowish, a little juicy, agreeable but lacking in perfume. Earliness and beauty should make it one of the most profitable on the market. In 1908 "enormous and handsome fruit of very first quality." Adopted by Congr.Pomol. 1908. Well known and valued at Lyon. One of the first varieties on the market. Mid-July to late July. In Bouches du Rhone even in late June sometimes. In 1893 Pelissier stated that this variety, raised by him in 1886, presents great similarity in wood and foliage with Abricot Peche (de Nancy) from which it may be descended, but fruit much larger and earlier. Tree very productive: fruit very firm and ships well. Hence partioularly valuable as commercial variety. Auguste Pelissier et fils originated also Bigarreau Pelissier, Bigarreau tigre, IAbricot rose or blane rose, ete.

Revue Horticole 1901, pp.460.462. Masele. Placed on list for trial Congres. Pomol. de France.

Listed by 2 of 26 French catalogs examined $2 / 27 / 42$. Not listed by 2 Belgian and 1 Swiss catalogs examined $2 / 27 / 42$.

Evaluation Data U. S. Plant Introduction Garden, Chico, Califomia.

P.I. 109992. Dr. Mascle. Plants received from H. Brayard, Directeur de Ia Station Experimentale, Marrakech, Morocco, March 1935. Fruit picked at Chico 6/30/41 and $7 / 18 / 42$. Season 6/30-7/10/41. The 1942 picking was probably past its prime. Size tends to be variable, mediun to large. Skin color yellow to greenish yellow, red blush, medium thickness and toughness. adherent to flesh, pubescence light, dots few, small, brown. Flesh color pale yellow to greenish yellow, juice abundant, slight yellowing, texture medium, firm, tender, juicy, crisp to melting, Flavor sweet, subacid, sprightly。 Quality fair to good. Stone free, small to medium, roundish oval. plump to flattered, blunt, smooth, brows, winged. 


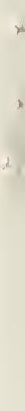


Tine of full blocm: 3/18/48, 3/14/49,3/4/50,3/18/51,3/12/53, averaging 3/13. Arerage date of full bloom for Blenhein this same period is $3 / 11$, Tizton $3 / 12$.

\section{Comments}

1941. Pale skin and flesh color. Good flaror and flesh texture. Size fair. Kernel bitter. Clean fleasant taste. Save for selecticn work. Yield heavy for a joung tree. Tree high to medium vigos, cleas, healthy with good bearing habit. From a sample sent from Chico and examined at Glenn Dale, Maryland, July 1, 1941, the follow ing notes were recorder: coarse skin, dry flesh, somewhat rubbery. very firm when ripe, uileven shape, poor color. Valuable factors are fimmess of flesh and shipping quality.

1942. Mild pleasant flavor. Should have a bit more volume. Pale color. Flavor and texture better than average. Very late ripening. Iight amount of shot hole.

1950. Browning at pit.

Of 87 seedlings and varieties rated in 194x. Dr. Mascle was 21 in the list with a score of 107 of a possible 150, divided as follows:

Keeping quality 40/40, attractiveress 10/30, flavor 15'?n, size 9/10, color 4/1n, quality of flesh $9 / 10$, seed size and cavity 710 disease of fruit $7 / 10$, freestone 10/10。

Of 52 seedlings and varieties rated in 1942. Dr. Niascle was 6 on the list with a score of 109 of a possible 150, divided as follows:

Keeping quality 35/40, attractiveness 15/30, flavor 12/20, size 9/10. color 4/10, "ality of flesh 9/10, seed size and cavity 6/20, disease of fruit $9 / 10$, freestone 10/10。

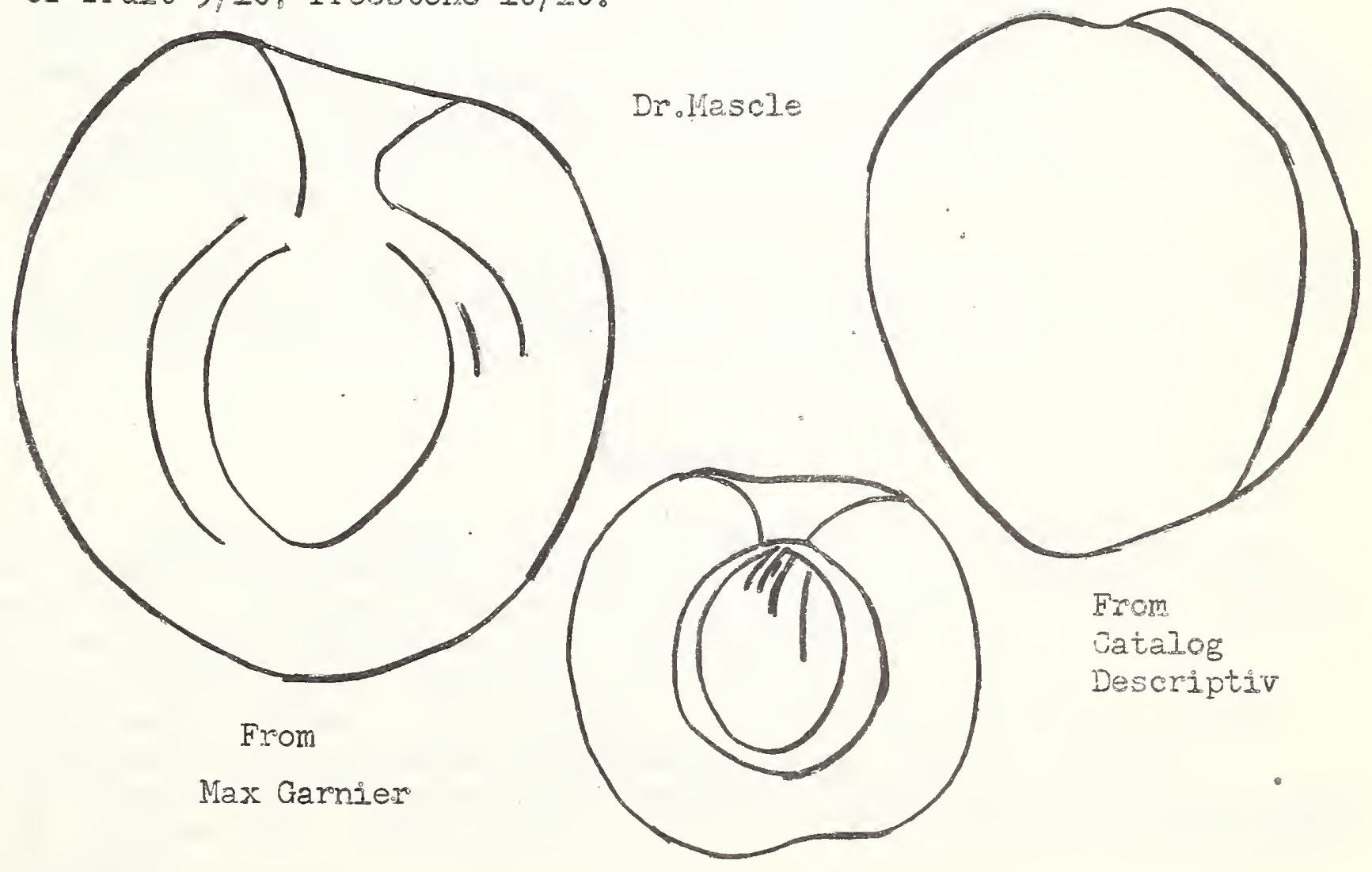

As Grows at 
4 


\section{Literature and Miscellaneous Notes}

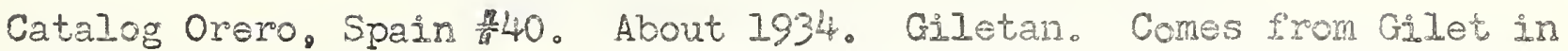
Valencia, whence its name. Tree of great growth and abundart produc tion. Fruit very large and the most resistant to shipment. Being much sought at present in the region near Valencia. Fixternally of good yellow and lively red. Flesh very firm, perfumed and sweet. June 20-30. Listed under commercial varieties.

Evaluation Data U. S. Plant Introduction Garden, Chaseo California

P.I. 9645I. Giletan. Originally from Spain, plants were received from Ho Brayard, Directeur, Station Experimentale, Marrakech. Morocco, January 1932。 Fruit picked at Chico 6/14/37,6/22/38,6/20/39 and 6/11/41 with seasons of $6 / 14-20 / 37,6 / 20-28 / 38$ and $6 / 12-22 / 39$. But few fruits in 1939 . medium orop in 1941. Hangs tell. Size uniform, fairly large, averaging $4.7 \mathrm{~cm}$. In length. $4.9 \mathrm{~cm}$. in diameter and $62.4 \mathrm{gms}$. In weight, with respective ranges of $4.0-5.2 \mathrm{~cm}, 0.4 .3-5.4 \mathrm{~cm}$, and 43.4 to $77.4 \mathrm{gms}$. 2937 to 1941. Shape roundish to roundish truncate, diameters and halves unequal. Cavity mostIy medium deep, she1zowin in 1941, varoying medjum to wide, regularly flaring, Suture lips slightly unequal, variable, chang ing from shallow to mediurn with some deep at base, distinct. Aper variable roundish to flattened, depressed. Pistilliary point a scar. Skin color orange yellow, blushed where exposed to sun, lively, medium in thickness and toughress, tart, adherent to flesh, pribescence short and light to very light, no bloom: dots few, smal", mostly obscure but some are red-purple. Stem medsum to thick $3 / 16$ to $1 / 4$ inch long. Flesh color orange yellow throisghout, juice moderately abundant, orange yellow, texture fine grazined, firm, meat tender, may get mealy at times, jujey, melting, Flavor sweet, mildly sibacid to occasional tartness, sprightly, somewhat aronatic. Quality good. Stone free, mostly medium size, oval, plunp, blunt, surface lightly pitted, brown. Kernel bitter.

Time of full bloom: $3 / 18 / 48,3 / 17 / 49,3 / 3 / 50,3 / 18 / 51$ and $2 / 26 / 53$. Average date for all years is $3 / 12$. Rienheim and Tilton are $3 / 11$ to 12 for the same period with dates of $3 / 2-3$ for 1950 and $3 / 6-$ ? for 1953.

\section{Comments}

1937. For canning or shipping. Not as highily colored as some of the comrnercial varieties but has some very good qualities. Pit loose in cavity. Kernel bitter. A shipment sent to Glenn Dale, Maryland, on June 2l, arrived in good condition. Attractive color, firm flesh. 1938. For home or market. Kernel bitter. Worthy of further observation. A shipment sent to Glenn Dale, Maryland, received there on July 2, 1938, was described as having unusual firmness but flavor rather neutral. 1939. Of 17 varieties rated as having commercial possibilities for the period 1935-39, Giletan ( $P$.I.9645I) with a score of 8 of a possible 10 was placed 4 on the list. 


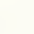




\section{Iiterature and Miscellaneous Notes}

Catalog Descriptiv des Fruits Adoptes, 1927,p。18. Commun. Synonyms: Abricot Crotte; Conice de Toulon; Gros Abricot ordinaire: Ronan: Transparent; Turkey。 Fruit fairly large, origin very ancient, Rounded, appearing generally oval. Suture thick, short. Cavity deep and irregular. Skin thick, deep yellow, washed with vermillion; blood red in the sun, often with small brown protuberant spots. Flesh amber yellow, hals f'ine, melting, juicy, sweet, aroma fine and delicate, Quality very good. Kernel bitter. JuIy. Recommended much for cooking, especially when grown as tall standard。

Bunyard, Handbook of Hardy Fruits, 1925. Common F. Commun。 (BrusseIs, Roman) Medium, early August, oblong-cval, a little flat sided with a narrow and deep suture, of which one side is larger. Colour, rather pale yeliow to orarge yeliow on surny side, which has dots or splashes of red brown. Flesh pale yellow, of inferior flavor. Stone oblong, rather flat, Lecres, rather small, roundish oval. Growth slender。Fertility, fair, Origin, a very old variety, which may go back to Roman times. Not now worth growing.

Thomas, American Fruit CuIturist, 1885. Roman (Abricot Commn)。 Medium In size, rather oval, compressed, suture small or obscure: surface pale yellow, with a few red dots to the sun: flesh very fine grained, half juicy, with a mild pleasant flavor. Kernel bitter. Worthless in England but greatly improved by our warm summers. Productive. Season rather eariy, or medium, or two weeks after midsummer. It is disseminated in this country under various erroneous names.

The blotch-leaved Roman differs only in the jellow spot or stain of its leaves.

Catalog of Bernay, France, 1938-39. Gros Comman. Fruzt large, flesh fine, fot cooking and syrup. Late July, early August (of the 3 groups arranged in order of ripening this is in the third).

Catalog of Bianchi, Italy, 1932-33. Commune (Romano; Gros ordinaire)。 Fruit rather large, irregularly globose; skin thick, lightly dowr. whitish yellow in shade, golden yellow in sun and covered with brown and russet dots. Flesh a handsome yellow: melting; freestone. First quality. Mid-July.

Catalog of Croux, France, 1938-39. Commun. Fruit fairoly large, good or fairly good according to the rature of the soil. Early August.

Catalog of Giannini, Italy, 1933-34. Commune. Fruit fairly large, almost spherical; of the best. JuIy.

Catalog of Lecolier, France, 1938. Commun (Gros Commun, Crotte, gaulex)。 Blossoms late。 Fruit fairly large, yellow with crimson, duroing July.

Catalog of Negree, France, 1933. Comice de Toulon, June, JuIy. Good. 


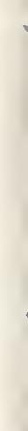


Catalog of Raverdam, France, 1932-33. Commun. Fruit fairly large, quality very good, tree vigorous and productive second half July.

Listed by 7 of 26 French catalogs examined $2 / 27 / 42$ as Cominun. Listed by 1 of 26 French catalogs examined 2/27/42 as Gros Commur. Iisted by 1 of 26 French catalogs examined $2 / 27 / 42$ as Comice de Touion. Not listed by 1 Swiss and 2 Belgian catalogs examined 2/27/42. Listed by 2 of $?$ Italian catalogs examined $3 / 2 / 42$.

\section{Evaluation Data}

\section{U. S. Plant Introduction Garden, Chieo, California}

F. F. 202562. Commune (Commun). Plants received from G. Giannini. Stabilimento disrticoltura, Pistoia, Italy, April 1933. Fruit picked at Chico, 6/30/38 and $6 / 15 / 39$ with seasons of $6 / 24-7 / 2 / 38$ and $6 / 13-20 / 39$. Hangs fairly well. Size quite uniform wh average length of $4.1 \mathrm{~cm}$. diameter $4.3 \mathrm{~cm}$, and weight $38.6 \mathrm{gms}$. ranges are $4.0-4.2 \mathrm{~cm}$. for length, $4.0-4.6 \mathrm{~cm}$ for diameter and 37.3 to 40.0 gms for weight. Shape roundish oblate, halves unequal. Carity medium to medium deep, mostly medium wide, rather abrupt, ridged, out deeply by suture. Suture medium in 1938, shallow in 1939, distinct. Apex variable, some rounded but others flattened, slightly depressed. Skin color dull creamy to pale yellow, lightly blushed, thin to medium thick, medium tough, slightly astringent, adherent to flesh, pubescence short, very fine, dots inconspicuous, stem thick, $.5 \mathrm{~cm}$. lone. Flesh color creamy white to pale yellow, ilghter at pit, otherwise even distribution, moderate juice, texture fine grain, some stringiness, tender, melting: flavor sweet, subacid, mild: quality fair to poor. Stone free, medium size, roundish-oval, plump, blusit, surface pitted, brown.

Comments: 1938. Poor color. 1939. Darkens at pit. No commercial value.

For the period 1935-39 Comme (P.I.102562) rated 1 out of a possible 10 score with Di Breda. Trevatt and Pesca di Nancy scoring 8, 7 and 6, rospectively. Poor color, darkens at pit, stringr, semi-elirg.

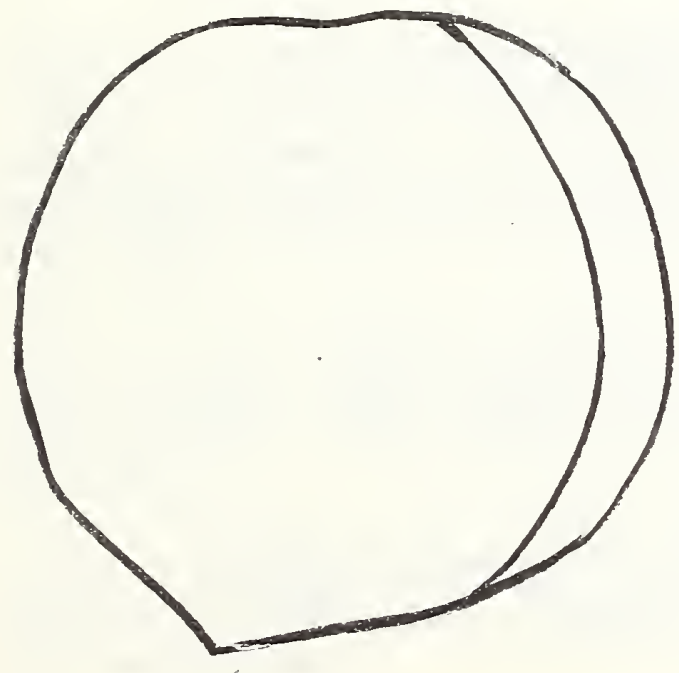

From Catalog Deseriptiv 1927

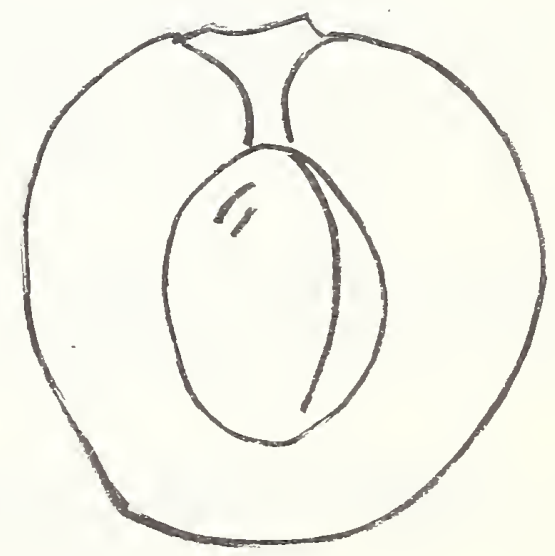

P.T. 202562 Commuss 



\section{Iiterature and Miscellaneous Notes}

Bunyard, Handbook of Hardy Fruits, 1925. Breda. Iind。Pom。Brit, III, I46 F。, Aveline (Hollande). Medium, mid-August, rourd, flattened each end, often a little compressed on the sides, suture rather deep. Color rich orange with a dark brownish red flush. Flesh orange, tender, fairly good and sweet. Stone free, round, kernel sweet, Growth moderate, very fertile. Leaves roundish oval, really more spear head shaped, finely pointed, serrate. Origin according to Miller this came originally from Africa (through Tradescant ? ) but imported into England from Breda. Hogg thinks our Breda cannot be this as Miller described it as large. It was, however. large in Miller's day compared with the other varieties then cultivated. A hardy variety. fruiting occasionally as a standard in warm situations.

Hogg。. Fruit Manual, 1884. Listed as Breda.

Thomas, Arnerican Fruit Culturist, 1885. Breda (Holland, Amande Aveline)。 Rather small, sometimes nearly medium (an inch and a half diameter). roundish, obscurely four sided, suture distinct, Surface orange with a dark reddish orange cheek. Flesh deep orange, free from the stone, rich and highly flavored. Sweet kernel. Quite early. or a week or two after midsummer. Hardy for an apricot and very productive.

Catalog of Bobeth, Germany. 1938-39. Von Breda. Ripens early to middle to end of August. Very fine pineapple-like flavor. One of the best liked varieties.

Catalog of Böttcher and Bergfeld, Germany, 1936-37. Breda-Aprikose。 Fruit medium size, dark yellow with some red, Flesh yellow, soft. pineapple spiced. Tree medium sized, very frutifu. Eariy to midaAugust。

Catalog of Fruit Trees, Bunyard and Company, England, 1938-39. Breda. Medium, mid-August, roundish, rich orange with brownish-red flush. Flesh tender and sweet. One of the hardiest and best cropping varieties which has been grown in this country for several centuries. (Grown as Maidens and Fans).

Catalog of J. Cheal \& Snne. Fngland, 1938. Breda. End of August. Small, rich flavor. Very hardy (Sold as dwarf fan trained, larger trees and maiders).

Catalog of Dahs \& Nevenfels, Germany, 1939-40. Breda aprikose. Highly valued for table and conserve. Trees of moderate vigor, not susceptible and productive. 
4 
Catalog of Goos \& Koenenann. Germany, 1938-39. Aprokose von Breda. Medium size jellow with red, fine pineapple-ijke flavor, early to midile of August.

Catalog of Hillier \& Sons, England, 1937. Breda. Snall, roundish, orange mottled red, flesh orange, flavor fairly good, very hardy and prolific. Used as standard in open ground in warm localities. Mifa-August.

Catalog of Laxtor Bros., England, 1938. Breda. Midole of August. Medivin size, roundish, good flavor, freestone。

Catalog of Sohloesser, Germany, 1938-9. Von Breda. Very fine for manufacm turoing.

Catalog of Schmidtz-Hubsch, Germeny, 1939-40. Aprikose aus Breda. Grourd color orange yellow, marbied dark, flesh vellowish, good market variety. Early to past middle August. Fruit round, medium size, table, freestons. Likes noist and rich soil, protected location. Blossoms tender to frost.

Catalog of Schwintzer, Italy, 1937-38. Di Breda. July. Medium size, yellow, duII red, perfumed. Tree hardy and very productire.

Catalog of Sgaravatti. Italy, 1932-33. Di Breda. Medium, pale, dull yellow, bright red, kernel sweet. July.

Catalog of Spooner \& Sons, Hounslow, England, 1916-1?. Sezson early. Medium size, highly flavored. A very hardy kind, it may be grown as a standard.

Iisted by 19 of 33 German catalogs examined 2/11/42.

Listed by 7 of 15 English catalogs examined $2 / 25 / 42$.

\section{Bvaluation Data \\ U. S. Plant Introduction Garden, Chico, California}

P.I. 65984. Di Breda. Trees received from Fratel1i Sgaravatti, Saonara, Padova, Italy, 1926. Fruit picked at Chico, 6/27/33,6/16/34,6/13/39. $6 / 18 / 40$ and $6 / 20 / 41$ with seasons of $6 / 10-16 / 39,6 / 18-22 / 40$ and $6 / 18-26 / 41$. respectively. Fruit hangs well. Size fairly uniform, $4.9 \mathrm{~cm}$. in lergth. $4.8 \mathrm{~cm}$. in diameter and $55.1 \mathrm{gms}$. in weight. Shape uniform, regular, ovate. cordate, compressed opposite suture, halves unequal. Cavity medium depth, wide, flaring, cut by suture. Suture lips unequal, shaliow, distinct, half circumference of fruit. Aper roundjsh. Pistiliary point a scar。 Skin color greenish orange-yellow, uniform, some blush, dull, medium thick- 

ness and tough... ss, adherent to flesh, pubescence light, dots few. small, varying froi. inconspicuous to reddish brow. Flesh color deep yeliow to yellow-orange throughout, juice moderate, pale yellow, testure medium to coarse, tender but firm, juicy, melting. Flevor subacid, variable sweetness, some mild, aromatic. Quality good in 1939, fair to good in 1940 and fair ir 194I. Stone free, medium to large, mostly oval to ovalo ovate, plump, blunt, surface mostly pitted but some smooth, brown in color, suture winged.

Time of full bloom: 3/15/38,3/18/39,3/9/42,3/14/48,3/20/49,3/28/51, $3 / 27 / 52$ and 3/27/53. Average date of full bloom for all jears is March 19. Average date for Bienheim and Tilton during these same years, March II.

\section{Comments}

1932. An apricot of fine size and colcr. Quality good to very good, for canning and drying.

1933. Excellent quality. Has quality, size, color, ever size and shape, smooth around seed cavity.

1234. Very good to excellent, for canning and drying.

1939. A very good cot except for slight stringiness of flesh. A few days earlier than Blenheim or Tilton.

1940. Seems to withstand heat quite well. Good color and qualitv. 1941. Good size and flesh color. Flavor fair but not the best, lacking volume and sweetness. Fair external color. Tree large, spreading type. With a score of 113 of a possible 150, this variety rated 13th among 90 apricot seedlings and varieties rated on Juiy 6, 1941. This score was broken down as follows: keeping quality 35/40, attractiveness 22/30, flavor 10/20, size 9/10, color 5/10, quality of flesh $6 / 10$, seed size and cavity $7 / 10$, disease of fruit $9 / 10$ and freestone $10 / 10$. Trevatt rated 129 and Pesca di Nancy 119. Blenheim and Tilton were not rated. Kernel of Di Breda (P.I. 65984) is sweet.

Among apricots fruiting at Chico from 1935 to 1939 this variety rated third after Real Fino (P.I. 102854) and Paviot (P.I. 65992) for commercial potentialities with a rating of 8 in a possible 10. Good quality. size and color, firm, few days earlier than Blenheim or Tilton. For canning, shipping or drying. Slight stringiness in flesh. Trevatt had a score of 7 and Pesca di Nancy 6 in this rating.

This introduction appears to agree rather well with the published description. 


\section{Iiterature and Miscellanoous Notes}

Catalog Descriptiv des Fruits Adoptes, 1927. p.23. Docteur Mascle。 Raised in I886 by Pelissier, nurseryman at Chateaumenard (Bouches du Rhone). Fruit very large, cheeks flattened, suture accentuated and compressed as far as the tip. Iips a little protuding. Cavity deep and narrow. Skin yellow. with lively orangered, sometimes dotted with crimson in the sun. Flesh lively orange-yellow, fine, juicy, sweet perfumed, leaving a large carity around the pit. Quality very good. Kernel bitter。 Mid-July。 This variety one of the earliest on our markets. Should be grown in southern slope where it gives the best results. It will be necessary to thin out the interior of the tree to avc d internal confusion. facilitate coloration and increase the perfume of the fruits.

Garnier. Max. Abricot "Dooteur Mascle" Rev。hort。 82: 156-157. 1910. First appearance Soc. Pom. de France was in form of a conserve. In October 1900. Pelissier. fruit grower at Chateaurenard (Bouches-du-Rhone) sent conserves of three varieties. Dr. Mascle. Blane rose and Gros muscat rou de Provence. First considered best. Fresh fruit described in 1907 as large, handsome, yellow, lightly washed with vermiliion in the sun. Fruit has a fine flesh. Jellowish, a little juicy, agreeable but lacking in perfume. Earliness and beauty should make it one of the most profitable on the market. In 1908 "enormous and handsome fruit of very first quality。" Adopted by Congr.Pomol. 1908. Well known and valued at Lyon. One of the first varieties on the market. Mid-July to late July. In Bouches du Rhone even in late June sometimes. In 1893 Pelissier stated that this variety. raised by him in 1886 , presents great similarity in wood and foliage with Abricot Peche (de Nancy) rrom which it may be descended, but fruit much larger and earlier. Tree very productive: fmit very firm and ships well. Hence particularly valuable as commercial variety. Auguste Pelissier et fils originated also Bigarreau Pelissier, Bigarreau tigre, I'Abricot rose or blanc rose, etc.

Revue Horticole 1901, pp.460.462. Masele. Placed on list for trial Congres. Pomol. de France.

Listed by 2 of 26 French catalogs examined 2/27/42.

Not listed by 2 Belgian and 1 Swiss catalogs examined 2/27/42.

\section{Evaluation Data \\ U. S. Plant Introduction Garden, Chico, Califomia.}

P.I. 109992. Dr. Mascle. Plants received from H. Brajard, Directeur de la Station Experimentale, Marrakech, Moroceo, March 1935. Fruit picked at Chico 6/30/41 and 7/18/42. Season 6/30-7/10/41. The 1942 picking was probably past its prime. Size tends to be variable, mediun to large. Skirs color yellow to greenish yellow, red blush, medium thickness and toughness. adherent to flesh, pubescence light, dots few, small, brown. Flesh color pale yellow to greenish yellow, juice abundant, slight yellowing, texture medium, firm, tender, juscy, crisp to melting, Flavor sweet, subacid. sprightly. Quality fair to good. Stone free. small to medium, roundish oval, plump to flattened, blunt, smooth, brown, winged. 
Time of full bloom: 3/18/48,3/14/49,3/4/50,3/18/51,3/12/53. averaging 3/13. Average date of full bloom for Blenhein this same period is $3 / 11$, Tiliton $3 / 12$ 。

\section{Comments}

1941. Pale skin and Ilesh color. Good flavor and flesh texture. Size fair. Kernel bitter. Clean pleasant taste. Save for selection work. Yield heavy for a young tree. Tree high to mediurn vigor, clean, healthy with good bearing habit. From a sample sent from Chico and examined at Glenn Dale, Maryland, July 1, 2941, the 10llowo ing notes were recorded: coarse skin, dry flesh, somewhat rubbery。 very firm when ripe, uneven shape, poor color. Valuable factors are firmess of flesh and shipping quality.

1942. Mild pleasant flavor. Should have a bit more polune. Pale color. Flavor and texture better than average. Very late ripening. Light amount of shot hole. 1950. Browning at pit。

of 87 seedlings and varieties rated in 1941. Dr. Mascle was 21 in the list with a score of 107 of a possible 150, divided as follows:

Keeping quality 40/40, attractiveness 10/30, flavor 15'? ? size 9/10, color 4/10, quality of flesh 9/10, seed size and cavity $7 / 10$, disease of fruit $7 / 10$, freestone 10/10。

Of 52 seedlings and varieties rated in 1942, Dr. Wascle was 6 on the list with a score of 109 of a possible 150, divided as follows: Keeping quality 35/40, attractiveness 15/30, flavor $12 / 20$, size 9/10。 color 4/10. rality of flesh 9/10, seed size and cavity 6/10, disease of fruit $9 / 20$. freestone 10/20.

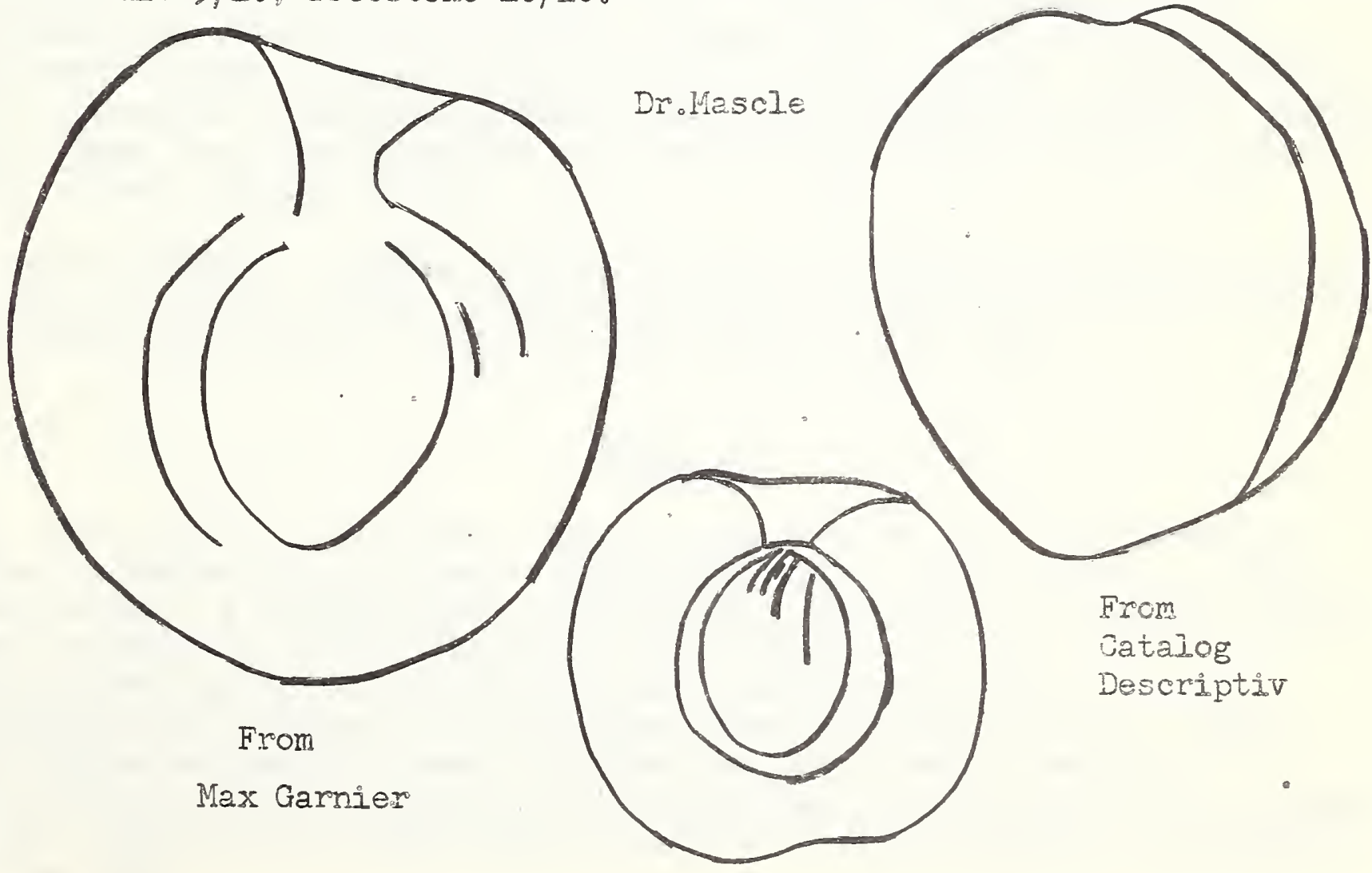

As Grows at

Chico 2941 . 



\section{Literature and Miscellaneous Notes}

Catalog Orero, Spain er40. About 1934. Giletan. Cones from Gilet In Valencia, whence its name. Tree of great growth and abundant producm tion. Fruit very large and the most resistant to shipnent. Being much sought at present in the region near Valencia. Externally of good yellow and lively red. Flesh very firm, perfumed and sweet. June 20m30. listed under commercial varieties.

Evaluation Data

U. So Plant Introduction Garden, Chose California

P.I. 2645 I. GIletan. Originally from Spain, plants were received from H. Brayard, Directeur, Station Experimentale, Marrakech, Morocco, January 1932. Fruit picked at chico 6/14/37,6/22/38,6/20/39 and 6/1I/4I with seasons of 6/14-20/37,6/20-28/38 and 6/12-22/39. But few fruits in 1939 . medium orop in 1941. Hangs tiell. Size uniform, fairly large, averaging $4 . ? \mathrm{~cm}$. in length, $4.9 \mathrm{~cm}$. in diameter and $62.4 \mathrm{gms}$. in weight, with respective ranges of $4.0-5.2 \mathrm{~cm}, 4.3-5.4 \mathrm{~cm}$, and 43.4 to $77.4 \mathrm{gms}$. 1937 to 1941. Shape ioundish to roundish truncate, diameters and halves unequal. Cavity mostIy medium deep, shellow in 1941, varying medjum to wide, regularly flaring. Suture lips slightly unequal, variable, chang. ing from shallow to medium with some deep at base, distinct. Apex variable rowndish to flattened, depressed. Pistillary point a scar. Skin color olange yellow, blushed where exposed to sun, lively, medium in thickness and toughness, tart, adherent to flesh, prbescence short and Iight to very light, no bloom: dots few, smal', mostly obsture but some are red-purple. Stem medium to thick $3 / 16$ to $1 / 4$ inch long. Flesh color orange yellow throughout, juice moderately abundant, orange yellow, texture fine grained, firm, meatr, tender, may get mealy at times, jujey, melting, Flavor sweet, mildy sibacid to occasional tartness, sprightly, somewhat aromatic. Quality good. Stone free, mostly medium size, oval, plump, blunt, surface lightly pitted, brown. Kernel bitter.

Time of full bloom: $3 / 28 / 48,3 / 17 / 49,3 / 3 / 50,3 / 18 / 51$ and 2/26/53. Average date for all years is $3 / 12$. Rienhem and Tilton are $3 / 11$ to 12 for the same period with dates of $3 / 2-3$ for 1950 and $3 / 6-$ f for 1953 .

\section{Comments}

1231. For caming or shipping. Not as highly colored as some of the commercial varieties but has some very good qualities. Pit loose in cavity. Kernel bitter. A shipment sent to Glenn Dale, Maryland, on June 2l, arroived in good condition. Attractive color, firm flesh. 1938. For home or market. Kernel bitter. Worthy of further observation. A shipment sent to Glenn Dale, Maryland, received there on July 2, 1938. was described as having unusual firmness but flavor rather neutral. 1939. Of 17 varieties rated as having commercial possibilities for the period 1935-39, Giletan (P.I. 96451) with a score of 8 of a possible 10 was placed 4 on the list. 


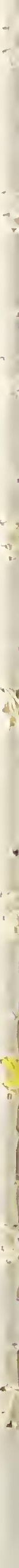


1941. Good color of flesh, appetizing flavor and external appearance. A shipment sent to Glenn Dale, Maryland, was descrobed as arroving in excellent condition. Color as good or better than Royal. Flesh color an attractive light orange. Flavor very good, far superior to P.I.6599l. Particolare. Should be promising as a fresh fruit shipper.

of 87 seedlings and varieties rated and scored in 1941 Giletan (P.I.9645I) 20t! on the list with a 1.09 of a possible 150 score, broken down as follows: keeping quality 25/40, attractiveness 18/30, flavor $17 / 20$, size 7/10, color 6/10, quality of fiesh 8/10, seed size and cavity $9 / 10$, disease of fruit $9 / 10$, freestone 10/10. Trevatt (P.I.68355) and Pesca di Nancy (P.I.65994) scored 129 and 119. rating them 2nd and loth on the Iist. Yield medium. fruit cleas. Tree a good type, high vigoro clean.

\section{Evaluation Data on a Second Introduction}

P.I. 101847. Giletan. Plants received from H. Brayard, Directeur de Ia Ferme Experimentale, Marrakech, Morocco, January 1933. Fruit picked $6 / 21 / 37,6 / 19 / 39,6 / 14 / 40,6 / 11 / 41,6 / 29 / 42$ and $6 / 13 / 44$, average 6/18. Season $6 / 18-26 / 37,6 / 16-23 / 39,6 / 12-20 / 40$ and $6 / 7-18 / 44$. Hangs wel1. SLas uniorm, large, averaging $5.0 \mathrm{~cm}$. In lengtl $5.4 \mathrm{~cm}$. in diameter and $78.6 \mathrm{gms}$. In weight, with ranges of 4.2 to $5.3 \mathrm{~cm}$. for length. 4.8 to $5.0 \mathrm{~cm}$. for diameter and 63.5 to $87.0 \mathrm{gms}$. for weight. Shape uniform, mostly regular, roundish oblate, halves and diameters unequal. Cavity shailow to medium deep, mostly medium width, regular, variable flaring to abmupt, cut by suture. Suture Iips unequal, shallow two jears, medium depth one, distinct. Apex variable roundish to flattened, some lightly depressed. Pistillary point a scar. Skin color mostly lively orange. yellow, some greenish-yellow, mostly medium thickness but about half divided between medium and tough skin, adherent to flesh, pubescence short and light, no blocm, dots small, mostly inconspicuous, obscure. Stern medium to thick, .5 to $.6 \mathrm{~cm}$. long. Flesh color largely oranges yellow, even distribution throughout: juice moderate to abundant, mostly paleryellow, texture variable but some coarse, some medium, firm, meaty, tender, some mealiness, moderately juicy, melting, Fllavor mildly subacid to sonewhat tart, variable sweetness. Quality fair to good. Stone free, medium size, oval, plump, blunt, pitted some years, smooth others, winged, light brown. Kernel bitter.

Time of full bloom 3/18/48,3/19/49,3/3/50,3/17/51 and 3/11/53, average 3/15. Averages for Blenheim and Tiltor for the same period are $3 / 11$ and $3 / 12$, respectively。

\section{Comments}

1937. For drying and shipping. Good size. A good firm cot, of possible value. Kernel bitter. From sample sent to and examined at Glenn Dale. Maryland, quality poor to fair, but little sort when sampled。 Size. flesh color, freestone, etc, worth watching.

1932. Doubtful value.

1940. Seems to withstand the hot weather fairly well. Large size because of smald crop. 

194I. Needs more flavor. Deep suture at the base spoils the appearance. Rather a rich color throughout. Kernel bitter. Crop heavy, well distributed over tree. Good type tree, clear, clean and high vigor。 1942. Good extemal and flesh color. Very pleasant flavor but a slight tendency to be flat, should have more volume. Does not pit burn readily. Ripens evenly throughout fruit. Ripe fruit seems to hold up well.

Light yield, high vigor, very light amount of shot-hole. 1944. Appearance and quality very good. Quality superior to Defarge and size about equal.

Of 87 seedlings and varieties rated and secred in 1942 this introduction of Giletan (P.I.I01847) was 25 on the list (20 for PoI。9645I above) with a rating of 105 of a possible 150 score. This was broken तnwr as follows: keeping quality 15/40, attractiveness 28/30, flavor $12 / 20$, size $9 / 10$, color $9 / 10$, quality of flesh $6 / 10$, seed size and cavity $7 / 20$. disease of fruit 9/10, freestone 10/10。

Of 52. seedlings and varieties rated and scored in 1942 this introduction ( $\mathrm{P} . I_{0}$ 101847) was 2 on the list with a rating of 118 of a possible 150 score. This was broken down as follows: keeping quality 30/40, attractiveness 25/30, flavor 12/20, size 9/10, color $8 / 10$, quality of flesh $8 / 1$, seed size and cavity $7 / 10$, disease of fruit $9 / 10$, freestone 10/10。

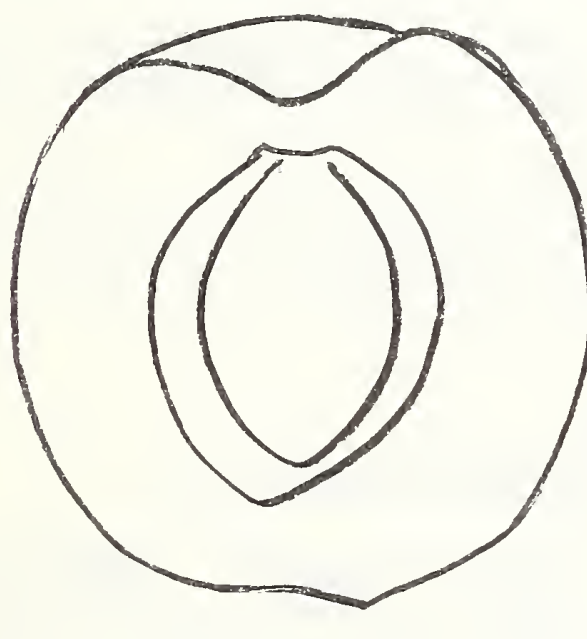

P.I. 96451

Giletan

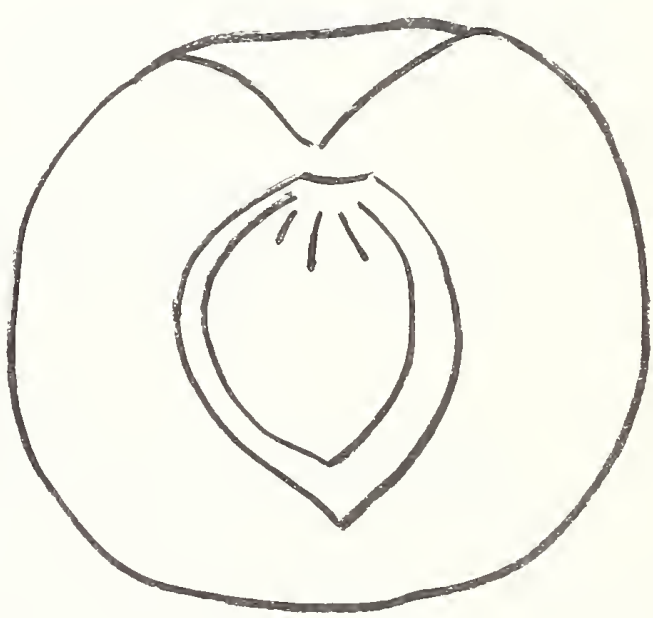

P.I。10184?

Gisetass

An anonymous rote has indicated that No, 16, Rouge de Roussillon (P.I. 117700) "May be identical with or close to the variety Giletan." A comparison of fruit outlines made under Rouge de Roussillon does indjcate some similarity in shape but the one year's description does not agree closely otherwise with that given for Giletan in 1939 or any other year. 

Literature and Miscellaneous Notes

Catalog Descriptive Scciety Pomologique de France, 1927. p.25. Liaband. Raised by M. Liaband, fruit grower at Iyon. Frait large or very large. generally spherical, sometimes ovoid. Cheeks little swollen。 Suture narrow, deep at base, lips almost equal. Cavity narrow and deep. Skins fine, pale, flat yellow, shaded with red in the sun. Flesh pale jellow。 transparent, fine, very melting, sweet and perfumed like Abricot de Nancy。 Qualt ty very good. Seed is bitter. Ripens early July. This early blossoming variety should be growri in sheltered situations to insure a crop. Especially suited for growing in an orchard but should be in warm regions little subject to spring frosts.

Hogg, Manual of Fruits, 1884, p.266, says hardy and a good bearer。

Catalog of Baltet, France, 1939-40. Liaband. Productive, fairly large. good. Juit.

Catalog of Lecolier, France, 1938. Ifaband, Blossorns early。 Frult fairly large, orange jellow, very good. July.

Catalog of Palles-Remy, France, 1937-48. Liaband Large, well perfurned and sweet. In list of 10 varieties in sequence of ripening, this is 5 th following De Saluces and preceding Royal.

Catalog of Sgaravatti. Itaiv, 1932-33. Laaband。 Large, pale, yellow。 Flesh transparent, juics ard aromatic. JuIy。

Listed by 7 of 26 French catalogs examined $2 / 27 / 42$. Listed by 1 of 7 Italfar catalogs examined $3 / 2 / 42$. Not listed by 1 Swiss and 2 Belgiar catalogs examined $2 / 27 / 42$ 。

\section{Evaluation Data \\ U. S. Plant Introduction Garden, Chico, Califormia.}

P.I. 65990. Llaband。 Plasts received from Fratelli Sgaravatti, Sacrara, Padova, Italy, January 1936. Fruit picked 6/13/39, 6/10/4n, 6/3/4I and $6 / 12 / 46$ with seasons of $6 / 9-15 / 39,6 / 6-14 / 40$, and 6/9-18/46. Fruit drops readily. Size uniform, with average length of $4.9 \mathrm{~cm}$, diameter $4.7 \mathrm{~cm}$. and weight 57.6 gms。 Some variability in shape but mostly regular, roundish ovate with some roundisk oblate, diameters somewhat unequal, halves unequal. Cavity medium deep and medium wide, regular, mostly flaring but some medium abrupt, cut by suture. Suture lips unequal, uniformly shallow depth, dism tinct for two years and equal, changing depth with medium depth at base and shallow at apex for one year, distinct. Apex roundish. Pistillary point a scar。 Skin color greenish light yellow to greenish orange-yellow, blushed, duli: medium thick, fairly tough, astringent, even tart at times, adherent to pulp, pubescence light, occasionally light blocm, dots numerous, small purplish red. Flesh color yellow to orange-yellow, evenly distroibuted, juice moderately abundant, yellow, texture medium to coarse, slightly stringy, firm but tender, melting, some mealiness at times. Flavor sweet to sweet-subacid, 

mild but tart skin, slightly aronatic. Quality fair at best but usually poor。

Stone semi-cling, large, oval to ovate, flattened, most blunt, surface pitted, brown. Suture winged.

Time of full bloom: $3 / 15 / 37,3 / 20 / 38,3 / 18 / 39,3 / 8 / 42,3 / 9 / 46,3 / 5 / 48$, $3 / 27 / 49,3 / 6 / 50,3 / 15 / 51$ and $3 / 24 / 53$. The average for these years is 3/15: $1942-53$ is $3 / 23-14$ with $3 / 11$ and 3/10-11 for Blenheim and Tilton, respectively, this same period.

\section{Comments}

1939. No commercial value. Darkens at pit. For the peroiod 1935-39. liaband was given a rating score of 2 of a possible 10 with Di Breda and Trevatt scoring 8 and 7 . respectively. Darkens at pit, fair quality, semi-eIing。

1940. Low in quality. Darkens at pit in hot weather.

1941. Lacks flavor. Seed large in proportion to size of fruit. Color should be more even and brilliantly orange: green color should be masked before maturing.

1946. Ripe fmit drops readily. Sweet, very mild, lacks volume. Needs sugar and acid.

Of 87 seedlings and varieties rated and scored in 1941, Liaband ranked 50 with a score of 86 out of a possible 150 divided as follows: quality 25/40, attractiveness 20/30, flavor 5/20, size 8/10, color 7/10, quality 2/10, seed size and cavity 7/10, disease of fruit 7/20, semi-cling 5/10。

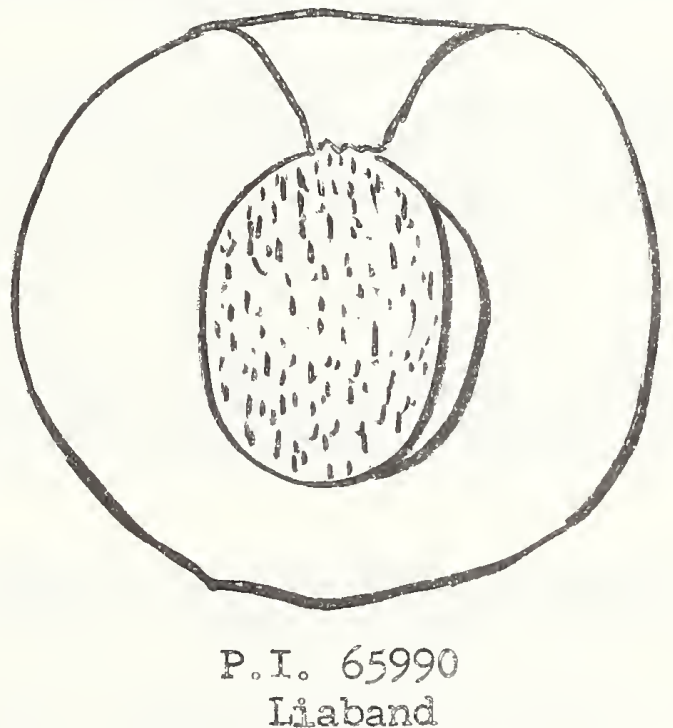

10. LUIZET

Prosus armeniaca

\section{Literature and Miscellaneous Notes}

Catalog Descriptir des Fruits Adoptes par le Congres Pomologique. Viliefranche 1927. p. 26. Luizet, Synonyms: Abricot du Clos: Suchet。 Raised by Moluizet, a nurseryman at Ecully-les-Ijon. Frut large or very large, ovoid, a litile obliquely truncate at tip. little compressed on the faces, with sutmre barely noticeable at tip and rery pronounced at base. Stalk in a very deep cavity. little excavated. Skin without spots, beautiful orange-jeliow, whith red 

becoming increasingly vivid in the sun. Flesh orange-yellow, solid, with sugary flavor, rather agreeably periumed。 Quality good, seed sweet, excellent for cocking. Ripens second half of july. Variety recognized as the most hardy of the species, grown especially as standard and in all exposires. Know in the South as Abricot Suchet, st is plasted in cono siderable quantity as well as in the other parts of France. where it is above all the export variety, thanks to the firmess of its flesh. It should be grafted generally on plum, but it has the property of uniting very well with almond. It may even be added that it is the oniy ore whose adhesion can be relied upon on this stock. No special pruning to be noted.

Bliu, Henri, Les varieties fruitieres a cultiver pour l'exportation. Rev。Hort. 80: 128-130. 1908. Gros Liszet Ls second on list of 8 varieties recommended as best for export. Fruit ovoid, swollen, fairly large, very good, polished gooseberry cream, liberally dotted with fawn. Flest firm, fairly juicy, vinous, pronounced flavoro Ripens late July. The Luizet is in hïgh demand for export. Tree hardy and productive. The Durde Iuizet, or Suchet, is also an excelient fruit for export, very resistant, enduring transportation well.

Buryard: Handbook Hardy Fruits, 1925. Luszet.Verger VIII, 4。 Medium to large, end July, evenly rounded each end. Color, bright orange with carmine flush and darker dots. Flesh deep Jellow, firm, sweet and rich. Growth vigorous. Ieaves medium, round heart shape, with short poist, fingly serrate。 Flowers small. A hardy variety, its rirm flesh suggest ing its value for mariket. Raised in 1838 by M. Gabriel Luizà. Nurseryman at Ecuity near Iyons, introduced in 1853.

Catalog of Berray, France, 1938-39. Lujat. Frut enormous, flesh firm, agreeably perfumed, very good for cooking ard preseroing in syrup. Late JuIy, early August. Of varieties arranged in three groups according to sequence of ripening, this is in the third。

Catalog of Bianchi, Italy. 1928-9. Luizet, (Du Clos) IIIus.p.19. Fruit. very large, elongate orojd, cheeks slightly pubescent, orangemyelzow dotted with purplish red: flesh firm, freestone, yellow. Very fertile and hardy。 juiy.

Catalog of Herm. A. Hesse, Neener (Bms). Hannover, Germany, 1938-39. Iists Luizet as sold in bush, not espalier form. No description.

Catalog of Laxton Bros.。 England, 1938. Luzzet。 July-August. Fruzt large, ovai, deep yellow flesh of gocd flarour.

Catalog of Lecolier. France, 1938. Luizet (Abricot du Clos)。 Blossoms mido season. Fruits pery large, ovoid, orange-yellow, very good, late July.

Catalog of Leyba, Sparin. About 1934. Luizet。 Orasge and bright red, very large, flesh firm and perfumed. Excellent for export and pulp. Middle to end of july. 


.


Catalog of Negree, France, 1934. Luizet, Early July. Fruit large. excelient, recommended for export.

Catalog of Orero, Spain, about 1934. Lujzet, Early July. Os general rather than on commercial list.

Catalog of San Juan, No. 29. Spain. About 1934. Lưzet. Large, golden yellow, flesh firm, pastosa, suitable for pulp. July.

Catalog of JoSchmitz, Germany, 1939-40. Luizet?'s Aprikose. Late July. Very large, roundish, orange-yellow with light red. Valuable table fruit of splendid appearance and flavor.

Cataleg of Sgaravatti. Italy, 1932-33. Luizet (Du Clos) (Colored figure). Variety much adapted to manufacturing conserves and export。 July.

Catasog of J。Timm asd Co. Elinshorn C.Hamburg, Germany, 1937-38. Lists Luszetaprikose。 Last of JuIy。

Catalog of Philipp Wo Jerner, Reichelsheim Im Odenwald, Germany, 1937-38. Luizet's Aprikose. Very large, orange yeilow, dotted red on sunny side. juicy, of splendid fine flavor。 last of July.

Catalog of Wilsdruff, Germany, 1938. Luizet, Ripens July. Very large. yellow, dotted red on surny side, juicy.

İsted by 11 of 16 German catalogs examined 2/21/42。

Iisted by 20 of 26 French catalogs examined $2 / 27 / 42$. This variety is one of four most frequentiy listed by French catalogs.

Listed by 1 of 2 Belgian catalogs examined $2 / 27 / 42$.

Iisted by $I$ of 1 Swiss catalog examined $2 / 27 / 42$ 。

Iisted by $?$ of $?$ Italian catalogs examined 3/2/42. Only variety listed so generally.

Listed by 1 of 15 English catalogs examined 3/2/42。

Evaluatior Data U. S. PIant Introduction Garden, Chico, California

P.I. 102434。 Luizet。 Plants received from Martino Bianchi。 Pistoia, Italy, Apri1 1933. Fruit picked at Chico 6/19/39,6/18/40,6/1I and 6/20/41, with seasons of $6 / 15-21 / 39,6 / 15-21 / 40$ and $6 / 27-25 / 4 i$. Hangs well. Size somewhat variabie, medium to large tith average length of $5.0 \mathrm{~cm}$. diameter $4.8 \mathrm{~cm}$. and wejght of $50.8 \mathrm{gms}$. Ranges of length 4 ? to $5.2 \mathrm{smog}$ diameter 1.7 to 4.8 m., and weight 37.8 to $61.8 \mathrm{gms}$. Shape somewhat variable but mostly cordate. some cordate-ovate, compressed along suture, diameters and halies unequal. Cavity somewhat variable but mostly deep. wide and flaring, occasionaliny medium to narrow and abrupt. Suture lips unequal, uniform depth but shallow one year and deep another, distinct. Apex roundish, pistiliary point a scar. Stem medium thickness, $.6 \mathrm{~cm}$. Iong Skin color greenish-yellow to orangeyellow, mostly even distribution, juice mederately abundant, colorless two venrs but colored another, texture mostiy medium but some coarseness, firm. tender, string some years, meal casion, but usually juioy, crisp. 

meltirig, flavor sweet, sometimes mild but usualiy somewhat subacid and even tart one year, sprightly, sometimes rather aromatio, quality fair to good. Stone mostly free, medium to large, mostly oval but some ovate, plump. blunt to bluntly pointed, surface mostly pitted, brown, winged suture. Kernel sweet.

Time of full bloom $3 / 7 / 42,3 / 8 / 46,3 / 12 / 48,3 / 19 / 49,2 / 28 / 50,3 / 18 / 52$ and 3/14/53, averaging $3 / 11$ for all these years: Blenheim 3/11 and Tilton $3 / 12$ for these same years.

\section{Comments}

1939. Rather small. Hold, said to be most adapted of all varieties. One of best exporting varieties because of firmess of flesh and good quality. For the period 1935-39. Luizet ( $P . I .102434$ ) rated 3 out of a possible 10 score where Di Breda. Trevatt and Pesca di Naney scored 8, 7 and 6 out of a possible 10, respectively. It was described as a quality good. meaty. sweet, with tough skin but rather small, semi-cling and slightly stringy。 1940. Firm, medium size this year, coarse flesh. Save.

1941. Poor, mottled external appearance is not attractive. Uneven but good size. Shape of fruit is bad. Pleasant full flavor, should be a bit sweeter. Kerrel sweet. Watch behavior of ripening closely as it tends to ripen unevenIy. Crop well distributed through tree. Tree upright growing with a weak crotch system. 1942. Fruit picked at Glenn Dale. Maryland, 7/10/42. Not fully ripe. Fruits small. Very severely cracked.

Notes added to descriptive sheet of apricots sent in to Glens Dale, Maryland. from Chico, Califomia, 6/II/41: P.I.102434。 Luizet. One or French standard varieties. Quality of mature fruits is good. Pronounced suture might be undesirable feature. Is located at Davis, California. Catalog of French Pomological. Society mentions that it is recognized as being the most hardy of the genus. Planted in considerable quartity for export trade due to firmness of flesh.

Or 87 seedlings and varieties rated and scored in I941, Iuizet (P.I.102434) was 18 with a seore of 212 out of a possible 150, divided as follows: keeping quality 30/40, attractiveness 20/30, flavor 15/20, size 9/10, color $7 / 10$, quality $8 / 10$, seed size and cavity $6 / 10$, disease of fruit $7 / 10$. freestone $10 / 10$.

\section{Eraluation Data on a Second Introductios}

P.I. 231289. Iuizet. Plants received from JoSchmit. Minchen, Germany. 


Catalog of Biarchi. Italy, 1932-33. Paviot, Splendid waroty with very large fruit: redish orange, exquisite, first quality. Valuable for export。 August.

Catalog of Giannini. Italy, 1933-34. Paviot. Fruit very large. One or the best late varieties. July-August.

Catalog of Ingegnoli. Italy. 1933, lists Paviot among late ripening varieties. No description.

Catalog of Leyba, Spain, about 1934, lists Paviot but no description given。

Catalog of Orero, Spain, about 1934. Paviot, Fruit enormous, average 100 gms. Compressed, shining orange, flesh fine, juzcy, sweet and very aromatic. Ripens lst of August. Listed under commercial varieties.

Catalog of San Juan, Spain, No.29, about 1934. Paviot. Fruit very Jarge, like a good nectarine. Golden yellow.flesh very firm, export variety。 Late July and early August.

Catalog of Sgaravatti, Italy, 1932-33. Paviot, Vexy large, some reaching 100 to 120 gins. Skin fine, orange-yellow and crimson. Flesh fine, melting, aromatic. Ripens late when other apricots have gone by. Fruit suitable for export and bence this variety can be recommended for commercial plariting. It constitutes a large part of the French and Swiss plants which are used for exporto July-August.

Listed by 10 or 26 French eat,alogs examined $2 / 27 / 42$. Listed by 1 of 2 Belgiar catalogs examined 2/27/42. Listed by 1 of 1 Swiss catalog examined 2/27/42. Listed by 6 of 7 Italian catalogs examined $3 / 2 / 42$.

\section{Evaluation Data \\ U. S. Plant Introduction Garden, Chico, California.}

P.I. 65992. Paviot. Plants received from Fratelii Sgaravatti, Saonara, Padova. Italy, January 1926. Fruit picked at Chico 6/12/39, 6/24/40 and 6/28/4I with seasons of $6 / 11-17 / 39,6 / 20-28 / 40$ and $6 / 25-7 / 4 / 41$. Hangs well。 Size fairly uniform, medium to large, averaging $4.1 \mathrm{~cm}$, in length, $4.3 \mathrm{~cm}$. in diameter and 36.4 gms. in weight for 1939 and $5.6 \mathrm{~cm}$. length, $5.3 \mathrm{~cm}$. diameter and 68.9 gms. in 1940. Shape fairly uniform; ovate to ovate roundish, compressed, halves unsqual. Cavity medium depth and width, regular, flaring, cut by suture. Suture lips unequal, medium deep in 1939, uniform and shallow in 1940, distinct, half the circumference of the fruit. Apex roundish, some pointed tips in 1939 but depressed in 1940. Pistillary point a star. Skin color yellow to greenish yellow, blushed $4-75$ percent pink to dark red. lively one year, dull another; mediun thickness and toughness though occasionally tough, adherent to the skin: pubescerce light, no bloom: dots few. small, mostly inconspicuous, those with color dark brown. Stem medium thick $.5 \mathrm{~cm}$. long。 Flesh color mostly orangeyellow, some may have greenish cast, even distribution: juice abundant, yellow: texture medium, tender, jư cy, melting, occasionaliy some mealiness and stringiness: flavor full, sweet, subacid, mild, sprightly, aromatic: quality fair to good but mostly good. Stone free, mostly medium size, some large, ovate, plump, blunt, pitted two years smooth one, brown, suture winged. Kernel bitter.

Time of full bloom 3/8/42,3/12/46,3/18/48,3/21,49,3/3/50,3/15/51 and $3 / 22 / 53$ 。 averaging $3 / 15$ for these jears:Blenheim $3 / 1$ l and Tilton $3 / 12$ for these same jears.

\section{Commeats}

1930. Frieit picked at Chico July 11. Crop normal. Fruit large, 3 I/4 oz.a roundisis, somewhat flattened at base and sides, diameter $21 / 4 \times 21 / 4$ iriog stem cavity medium depth, suture prominent but shallow, apex rounded, surface smooth, pubescence light, color skin golden-yellow tinged with red where exw 
posed to sun, skin thin but tough, flesh golden yellow, soft, juicy, sweet, pit large, free. A good apricot for shipping and drying".

1932. Good. A shipment to Glenn Dale, Marvland, arrived ir fair condition only. 1933. Picked 6/27. Excellent quality。 Fine color. Resistance to high temperature. Irregular shape, sides quite unequal.

1934. On 6/11 rated as very good quality and on 6/16 good.

1939. Fairly good quality, excellent texture and color. Much smaller this year. 1940. Promising.

1941. Large size. Fair shape. Uneven external color. Fair flesh color and full flavor. Yield mediun high. Tree vigor high: has short fruit spurs.

Of 17 varieties rated as having comercial possibilities for the period 1935-39. Paviot, with a score of 9 of a possible ten, was placed second on the list after Real Fino (P.I。 101854), which IIkewise had a 9 score. This variety was described as ha ing good quality, color, textwre, etc. ripening about the same season as Blenhelm and Tilton. For market use。

Of $8 ?$ seedlings and varieties rated and scored in 1941. Paviot was 7th with a rating of 123 of a possible 150 score. This was broken down as follows: keeping quality 40/40, attractiveness 20/30, flavor 15/20, size 9/10, color $6 / 10$, quality $6 / 10$, seed size and cavity $7 / 10$, disease of fruit $10 / 10$ and freestone 10/10。

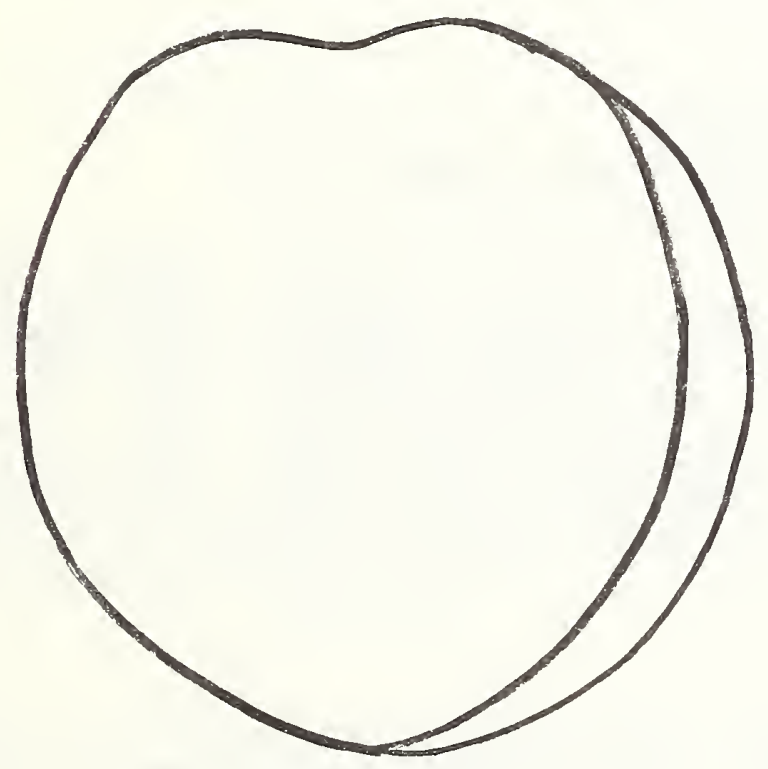

From Catalog Descriptiv

$192 ?$

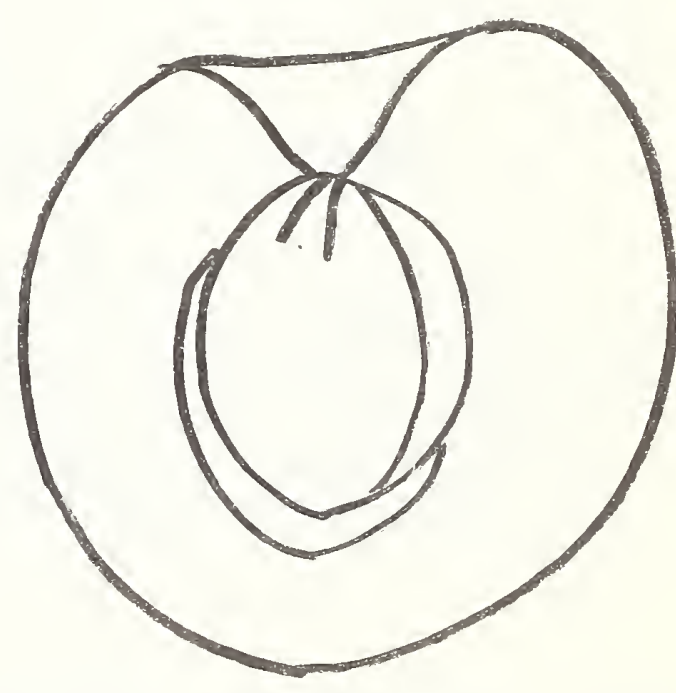

P.I. 65992

Paviot. 



\section{Literature and Miscellaneous Notes}

Catalog Descriptiv des Fruits Adoptes par le Congres. Pomologique, Villefranche, 1927, p. 29. Poizat. Raised by Mo Poizat, horticulturist at Neuvillemsur-Saone (Rhone)。 Fruit spherical, presenting a light point toward the pistillary point. Skin straw yellow, golden, and covered with vermilion in the sun. Flesh deep yellow, breaking, well sugared and perfumed. Stone small, free, with bitter kernel. Quality very good. Maturity first fortnight of August. Shoots short, short internodes dis. appearing because of the number of fruits in sumer, leaves wide and flattened, flowers of pinkish white. Tree very vigorous and very fruitful, suitable above all to intensive culture where it will give the best results. The fruit is particularly sensitive to Monilia and must be sprayed preventively.

Catalog of Lepage \& Cie, France, 1938-39. Poizat. Iisted as ripening in early August. Is 11 on list of 12 varieties in ripening season. One of seven varieties marked as a commercial variety.

Catalog of A. Veauvy, France, 1938-39. No description but lists apricots in order of ripening: Precoce de Bruel, Muscat, Suchet or Luizet, Ampuis,
Paviot, Poizat, Blane rose. Peche de Nancy. Bergeron.

Listed by 3 of 26 French catalogs examined 2/27/42。

Not listed by 1 Swiss and 2 Belgian catalogs examined $2 / 27 / 42$.

\section{Evaluation Data \\ U. So. Plant Introduction Garden, Chico, California}

P. I. 130974. Poizat. Plants received from Pepinieres A. Veauvy. July 6.1950 . Crest, France, November 29, 1948. Fruit picked at Chico July 6, 1950. Size large, over 2 I/4 inches, oval shape, skin and flesh orange color, medium to light blush, suture very shallow, quality good to excellent, sugar high, acid medium, aroma medium to medium high, juice rather dry, no fiber noticed, stone free, retention value of fruit
excellent and tree good.

Date of full bloom: $1948-3 / 19,1949-3 / 24,1950-3 / 6$, and $1951-3 / 20$ with an average date of March 17. Blenheim and Tilton average March 12
for this same period. 



\section{Literature and Miscellaneous Notes}

Catalog Descriptiv Society Pomologique de France, 1927. De Boulbon (Precoce de Boulbon)。 Origin unknown. Very important variety aroun Boulbon, near Tarascon. Fruit large, a little oblong, wider at the base. A little com pressed in the upper third, compressed on the faces, scarcely curving on the back, very curved at the suture, which is deep and bordered with unequal lips. Cavity moderate depth, folded, bumpy and small. Pistillary point in a considerable oblique cavity. Skin yellow, well colored with crimson in the sun with blood red spots. Flesh orange yellow. freestone, fine, melting, very juicy, sweet and perfumed. Quality very good, roipe fiirst half of July. This variety makes pretty trees as standards. It is growr on a very important scale in the south of France and can be likewise grown near the center and west.

Bliu, Henri. Ies varietes fruitieres a cultivel pour I'exportation. Rev。 hort. 80: 128-130. 1908. One of eight varieties listed as best for export. Excellent fruit, large or very large, skin smooth, orange yellow, marbled with pink and with crimson. Flesh fine, flavored, juicy and aromatic. Ripens early July. Tree very vigorous, productive, robust, form regular and splendid. Listed as earliest ripening of the ? varieties.

Catalog of Bernay, France. 1938-39. Precoce de Boulbon. Fruit large or very large, flesh fine and perfumed. Also good for cooking. Very good. First half July (in Normandy)。Follows Precoce de Montplaisir in ripening。

Catalog of Bianchi, Italy, 1932-33. Precoce di Boulbon. Large, yellow. colored with red in the sun. Flesh very fine, very savoury, aromatic. First of July.

Catalog of Croux, France, 1938-39. Precoce de Boulbon. Early variety of prime merit, ripening second half of July. Fruit enormous, flesh fine. honeyed, very agreeably perfuned.

Catalog of Giannini, Italy, 1933-34. Precoce de Boulbon (fig.1). Fruit large, with fine flesh, very good。 June-July.

Catalog of Herholdt and Sons, South Africa, 1939-40. Early Boulbon.A very early variety imported by us. Fruit is of large size, fine flavor and good quality.

Catalog of Iecolier, France, 1938. Precoce Boulbon. Blossoms early. Fruit large, oblong, yellow with crimson, good, first half of July.

Catalog of Leyba, Spain, about 1934. Precoce de Boulbon. Yellow, crimson, large, very pleasant, juicy, excellent quality。 June. 

Catalog of Negree, France, 1934. Precoce de Boulbon. Early July. Very large. Grows well in dry soils. Good for export.

Catalog of Orero, Spain, about 1934. Precoce de Boulton. Ripens early June. On general rather than commercial Iist.

Catalog of San Juan, Spain, about 1934. Precot de Boulbon. Very large, yellow tinted with red, flesh fine, medium consistency, agreeable and melting。 Mida--July。

Catalog of Sgaravatti, Italy, 1932-33. Precoce de Boulibon. Large, flesh fine, buttery. July。

Catalog of Timm. Germany, 1937-38 lists a variety Frühe von Bourbon. Farly August.

Listed by 16 of 26 French catalogs examined $2 / 28 / 42$.

Iisted by I Swiss catalog examined $2 / 28 / 42$.

Listed by 2 of 2 Belgian catalogs examined 2/28/42.

Listed by 4 of 7 Italian catalogs examined 3/2/42.

one of the 4 or 5 most papular varieties.

\section{Evaluaticn Data \\ U. S. Plant Introduction Garden, Chico, Califomia}

P.I. 65995. Precoce de Boulbon. Plants received from Fratelli Sgaravatti, January 1926. Fruit picked at Chico 6/11/28,6/18/30,6/6/39, and 6/5/46 with seasons of $6 / 10-20 / 35,6 / 5-10 / 39$ and $6 / 5 /-11 / 46$. Hangs well. Uniform size, averaging $5.0 \mathrm{~cm}$. for length, $5.0 \mathrm{~cm}$. diameter and $32.2 \mathrm{gms}$. in weight. Shape roundish, halves unequal. Cavity medium deep, wide, regular, flaring. Suture shallow, distinct. Apex roundish. Skin: color light yellow to yellow with up to 60 percent red blush: redium thickness and toughness: adherent to flesh; pubescence short and light; dots inconspicuous. Flesh: color yellow to orange yellow, distributed throughout: moderate juice: fine grain texture, tender, melting; flavor sweet, subacid, mild; quality fair at best but mostly fair to poor. Stone free, large, oval, plump, blunt, surface rough, brown.

Time of full bloom: 3/5/48,3/5/50,3/13/51, and 3/4/53, averaging $3 / 7$ for these years; for Blenheim and Tilton $3 / 10$ each during this same period。

\section{Comments}

1935 to 1939. Rated 2 of a possible 10 score for this period. Large pit; fair quality: cracks badly: ripens around pit first. Little or no commercial value. 1946. Soft. Mild apricot flavor. Pits tend to break off at lower one third (apical).A first picking was made on $6 / 5 / 46$ and a second on 6/12/46. Ripe fruit hangs very well. Sweet but very mild。 Quality fair to poor。 Gets soft and mushy。 Freestone.

Among a group of apricots picked on 6/5/46 and again on 6/12/46 this variety rated as one of the largest and best appearing of the group that had both yellow flesh and a blush. 

Another introduction. No. 3. Boulbon ( $P . I .73455$ ) has been described at Chico but apparently it is not the same variety as Precoce de Boulbors (P.I.65995). Trees of P.I. 73455 blossom a week later and ripen near Iy a week later (1939) and have a pale, creamy white flesh rather than yellow to orange-yellow.

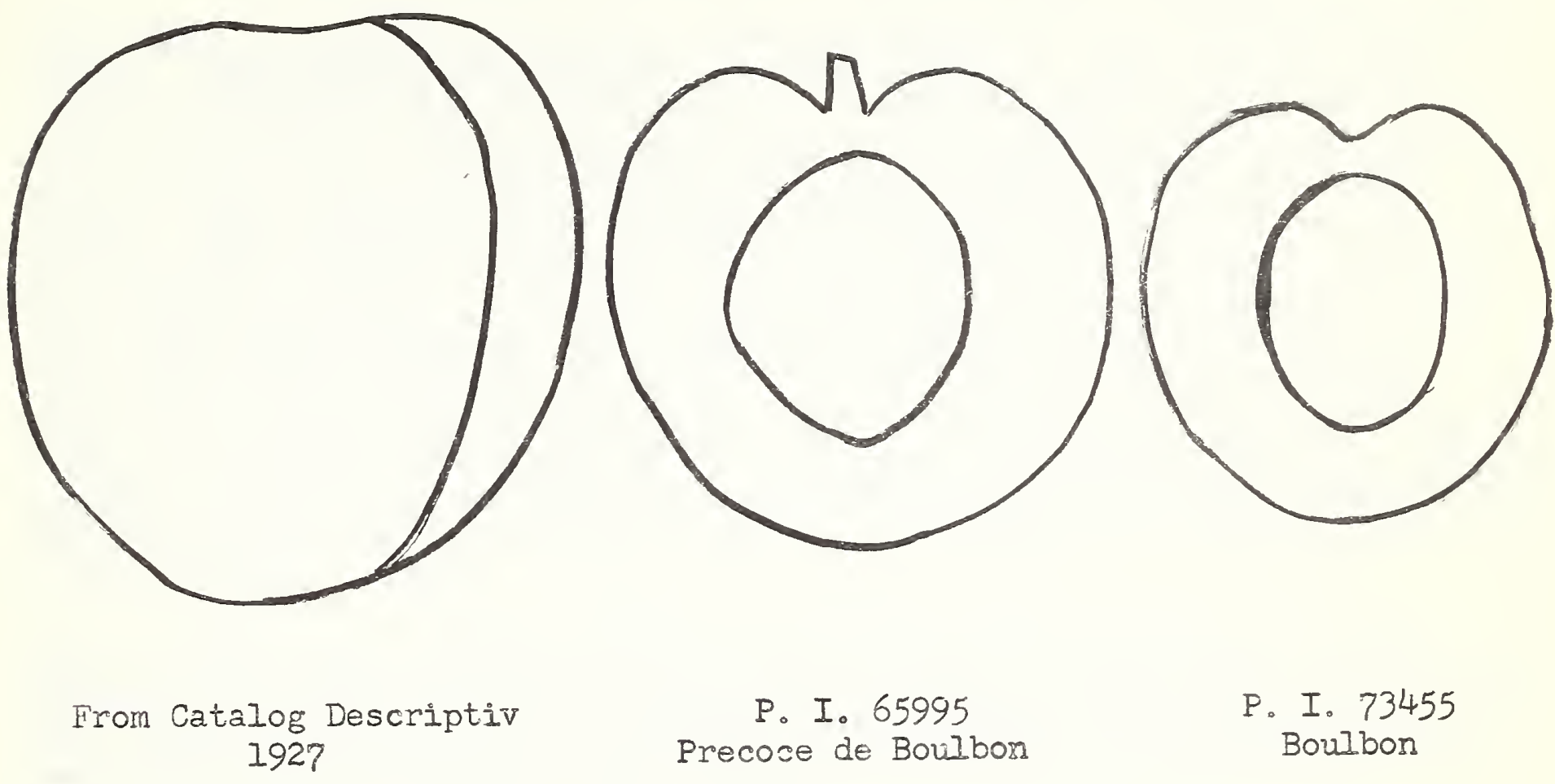

14. PRECOCE DPESPEREN

Prunus armeniaca

\section{Iiterature and Miscelleneous Data}

Not listed in Catalog Descriptiv des Fruits Adoptes, 1927.

Catalog of Baltet, France, 1938. Precoce Esperen. Vigorous, fairly large, straty-yellow, good。 July。

Catalog Bernay, France, 1938-39. Precoce d"Esperen. Fruit large, flesh fine, juicy, good. (Varieties arranged in three groups accordine to sequence of ripening; this in second group with Precoce de Bolik on and following Precoce de Montplaisir)。

Catalog of Lecolier, France, 1938. Precoce Esperen. (Precoce de Hongrie. gros abricotin). Blossoms early. Fruit large, ovoid, good pale yellow. July. (Precoce de Montplaisir given as ripening in early July). Lecolier catalogs Precoce d'Esperen as distinct from Commun.

Catalog of Negree. France, 1934. Precoce d'Esperen. Mid-June. Fairly prom ductive, soft.

Catalog of Rivoire, France, 1939-40. Precoce d"esperen. Fruit large, crimson. Flesh perfumed, very good. Mid-July。 Tree vigorous and productive。 

Listed by 10 of 26 French catalogs examined $2 / 28 / 42$.

Not listed by 1 Swiss and 2 BeIgian catalogs exarined 2/28/42.

Evaluation Data

U. S. Plant Introduction Garden, Chico, California

P.I. 117697. Precoce d'Esperen. Plants received from H. Brayard, Directeur. Station Experimentale de Marrakech, Morocco, March 9, 1936. Fruit picked at Chico 6/8/39 and 6/19/42 and 6/14/43. Season 6/5-10/39 and 6/14-18/43. Hangs well. Size variable, averaging $5.0 \mathrm{~cm}$ in length and diameter, and weight of $63.5 \mathrm{gms}$. In 1939: said to be large in 1942 but no measurements given. Shape variable, mostly roundish, halves unequal. Cavity shallow. medium width, regular, flaring. Suture shallow, distinct. Apex roundish. Skin: color greenish light yellow to orange yellow dull, blushed 5 to $10 \%$ with red: medium thickness and toughness; adherent to flesh; pubescence very light; dots few small, redmbrown. Flesh: color described as yeliow one year and white to orange another, unevenly distributed: juice moderately abuindant, yellow: texture medium fine grained, firm, tender, mealy but juicy. melting: flavor sweet subacid, mild. Quality mostly fair. Stone free, medium to large, oval, flattened, blunt, mostly smooth but some lightly pitted。 brown, slightly winged.

Time of full bloom: $3 / 6 / 50,3 / 26 / 51$ and $3 / 28 / 53$ with an average of $3 / 20$ 。 Blenheim and Tilton for these same years averaged $3 / 10$ and $3 / 8$, respectively. with dates of $3 / 2$ and $3 / 3$ in 1950 after an accumulation of 1075 hours at or below $45^{\circ} \mathrm{F}$. by February 1. By February 1, 1951, the accumulation was 766 hours and 859 hours by February $I_{0} 1953$.

\section{Comments.}

1939. Browning around pit. Doubtful value.

1942. Flavor needs more volume, flat. Fruit ripens unevenly. Much darkening around pit. Flesh should be much firmer in ripe fruit. Pit and cavity large. Yield very light. Vigor high. Fruit holds well on tree when ripe. Shot-hole Iight to medium.

1943. Crop very light. Fruit large, sweet, Tilton color, unequal halves. Tree vigorous, spreading。

of 52 varieties and seedlings rated and scored in 1942 Precoce diEsperen ( $P$.I. 137697) was 35th with a rating of 76 of a possible score of 150 . This was broken down as follows: keeping quality 10/40, attractiveness 15/30, flavor 7/20, size 10/10, color 4/10, quality of flesh $8 / 10$, seed size and cavity 5/10。 disease of fruit $7 / 10$, freestone 10/10. Trevatt rated first with a score of $119 / 250$ and Tilton 3 rd with $117 / 150$ 。

\section{Evaluation Data on a Second Introduction}

P.I. 136558. Precoce d'Esperen. Scions received from Professor P.T. Anagnostopoulos, Ecole Superieure d'Agriculture, Athens, Apriz 2940. No fruit of this introduction has been described at Chico. Time of full bloom: $3 / 19 / 48,3 / 18 / 49,3 / 7 / 50$ and $3 / 19 / 51$, with an average date of $3 / 15$. Average dates for BIenheim and Tilton this same period are $3 / 12$ and $3 / 13$. respectively。 

Literature and Miscellaneous Notes.

Catalog Descriptiv Society Pomologique de France, 1927. Frecoce do Montw plaisir. Chance seedling introduced in 2865 by M. Jacquier, fruit grower at Montplaisir, Lylon. Above medium size, regulariy ovoid, suture rather narrow and fairly deep, lips unequal. Cavity regular, narrow and fairly deep. Skin downy, thin, fine, of handsome orange-yellow, washed and stroiped with purple and crimson in the sun. Flesh orange-yellow, compact, very melting, very juicy, deliciously perfumed, quality very good, seed bitter. Late June and early July. Tree fairly delicate, preferably grown in espalier. Standard would be unfavorshte in view of its moderate vigor and its low productivity. Although it is one of the last to flower and consequently escapes spring frosts, it should always be grown in warm exposures and very temperate regions.

Catalog of Bemay. France, 1938-39. Precoce de Montplaisir. Frút fairly large, orange-yellow, flesh very melting and perfumed. Late June, early July。 (Tarliest ripening variety listed)。

Catalog of Bianchi, Italy, 1932-33. Precoce de Montplaisirr. Fruit large, flesh melting, aromatic. Best in spalier in warm exposure. June.

Not listed by Giannini, Italy, 1933-34. Ingegnoli。 Italy, January 1933 and Sgaravattı. 1932-33.

Catalog of Lecolier, France, 1938. Precoce de Montplaisir. Blossoms early. Fruit medium, ovoid, pale yellow, very good. Late June, early July。

Catalog of Orero. Spain, about 1934. Precoce de Montplaisir. MidwJune. On general rather than commercial list.

Ca.talog of Pallez-Remy, Franc 1937-38. Precoce de Montplaisis. Large, reddish, very juicy, very good, productive. In 10 varieties' sequence of ripening, this is second, following Gros Precoce and preceding Sowvenir d'Amic。

Catalog of Schloesser, 1938-39, Gernany, Frơhe von Montplaisir. Large, irregularly colored, early apricot.

Listed by 1 of 33 German catalogs examined 2/11/42。 Listed by 13 of 26 French catalogs examined $2 / 28 / 42$. Listed by 1 of 2 Belgian catalogs examined 2/28/42。 Listed by $I$ of 2 Swiss catalogs examined 2/28/42。 Listed by $I$ of 7 Italian catalogs examined $3 / 2 / 42$.

\section{Evaluation Data \\ U. S. Plant Introduction Garden, Chico, California}

P.I. 102435. Precoce de Montplaisir. Plants received from Martino Bianchi, Pistoia, Italy。Apri1 1933. Fruit picked 6/22/39 and 6/20/41. Season 6/21-29/39 and 6/18-29/4I。 Hangs well. Size fairly uniform, Iarge with average length and diameter of $4.7 \mathrm{~cm}$. and weight of $49.2 \mathrm{gms}$. Shape roundish, halves urequal. Cavity medium depth and width, regular, flaring to abrupt. 

Suture shallow, distinct. Apex variable, rounded to somewhat flattened and depressed. Skin: color has varied from Iight yellow to greenish orange yellow: blush varies from light to 75 percent of surface, dulli: medium thickness and toughness: adherent to flesh: pubescence short and light: dots small. inconw spicuous, brown when colored. Stem mediun thick, $06 \mathrm{~cm}$ long. Flesh: color varies from yellow through greenish orange-jelin nor and orange yellow distribution uneven; moderatel, juicy; texture mediu. carse, firm, meaty, medium tender, occasionally mealv, meltino; flavor mildiy subazid, fair sweetress: quality fair at best mostly fair to poor. Stone generaliy free though a cling from one tree. Mediun size, oval, plump, blunt, surface smooth, brows in color, wingeda Kernel
bitter. Time of full bloom: $3 / 23 / 38$ and $3 / 18 / 39$ : first leaf $3 / 28 / 38$ and $3 / 20 / 39$ for
trees at $\mathrm{E} 38-3,4$ 。

\section{Comments}

1939. Trees at $\mathrm{E}$ 38-3.4. Skin does not color up until it is quite ripe。 of dovibtful value. Fruit from these trees is supposed to be the same as P.I.I02435 at L I-3 but is later and different. Tree at I I-3. For home or local market. of ifttle commercial value but very attractive.

For the period 1935-39. fruit of trees $E$ 38-3,4 rated 3 of a possible 10 score with fairly good quality, good flesh color and size but skin unattractive and lacking in color: doubtful value and use. Fruit from tree at $\mathrm{L}$ l-3 rated 2 out of a possible 10 score with attractive, good size fruits. However, its rather dry. pale color, poor quality and cling stone characters make it of doubtful value. 1241. Trees E 38-3,4。 Good size, fair shape. Ripens unevenly。 Dull external appearance. Poor flavor, tends to be flat. Yiseld light to medium. Prolonged ripening. Tree vigor high. clean. Kernel bitter。 Recommended for discard. Of 87 seedlings and varieties rated and scored in 1941. Precoce de Montplaisir. (38-3.4 was 78th on the list with a rating of 63 of a possible 150 score. This was kroken down as follows: keeping qualit 5/40, attractiveness 10/30, flavor $7 / 2 v$, size $8 / 10$, color $2 / 10$, quality $8 / 10$, seed size and cavity $5 / 10$, disease of Iruit $8 / 10$, freestone $10 / 10$ 。

There are no further notes relative to the tree at I I-3 but from the above descriptions it appears that fruits of $\mathrm{E}, 38-3,4$ are more like the variety as
described.

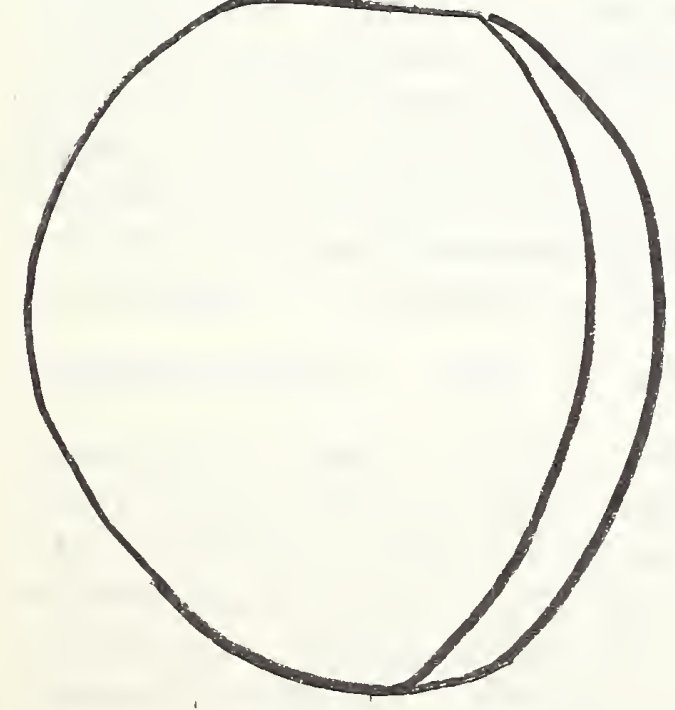

From Catalog Descriptiv 1927

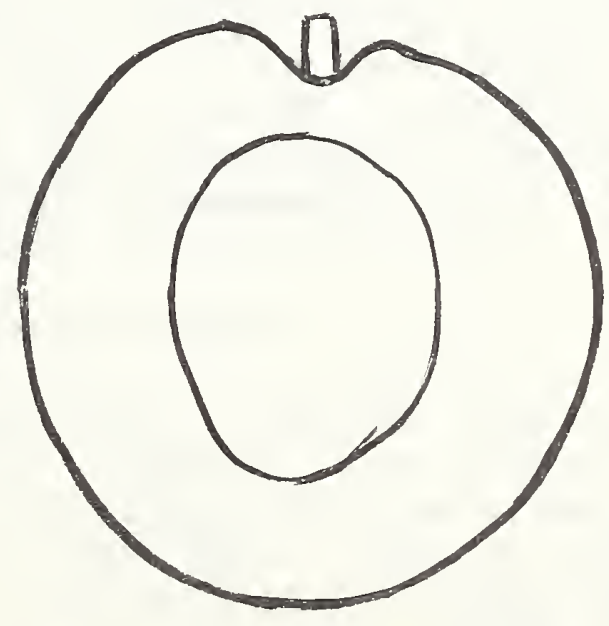

P。I. 202435

Tree I I-3

Precoce de Montplaisir

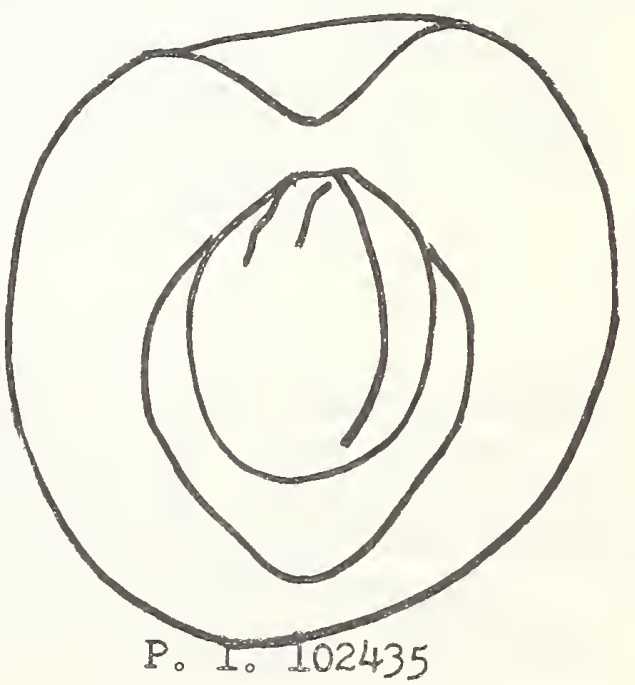

Trees $38-3,4$ 

Not Iisted in Catalog Descriptiv des Fruits Adoptes, 1927.

Bartre: Abrocot Rouge de Roussil1on. Pomol.Fr。1927. No.10, pp.182-184。 A very old variety raised about 1830 by my grandfather, Jean Marqui, but it was not until 1840 that it appeared in the catalnos of the house. It was not much planted at that time, people prefe, ring correctly the Abroot Peche de Nancy for regional consumption. It seems today that the Abricot Peche is in fuld degeneration, at least in our region (IIemsur-Tet), and it is now more than an amateur"s variety, perfect as to quality, but of little value for commercial plantings: further, it ships poorly. Attention was not called to the Rouge de Roussilion until exportation began with the development of our radinay network. Around 1860 communications to Paris were still very slow and the methods of packing defective. It was necessary, therefore, to seek fruits capable of enduring long voyages. In 1878, at the time of the Exposition Universelle de Paris, exportation took on considerable increase and the shippers of Roussilion, incited by the high retum secured or the Paris markets, began to invade foreign markets like London, Cologne, etc. The prices secured on these markets. Which considerably exceeded those of the Abricot Peche and even more the Abricot Commun or d'Alexandria, which was much grows here, directed the growers toward planting of Abricot. Rouge. The fruit is fairly large to large. oblong, elongated, a little ruunded on the two upper faces; the stem is short. compressed in a fairly deep cavity; skin fairly thick, greenish yellow, highly colored in the sun, often dotted with rather lively red spots. Flesh is pale yellow, half fine, very solid, but very melting when the fruit is very ripe. I add that this variety ripens very well only in the south and in warm regions. When it arrives on the market it is eminent and is always the first one sold. because of its beauty.

Tree is fairly vigorous, erect and always in form (in contrast to the luizet, which in our regions makes drooping trees with branches drooping). The wood is coarse, deep reddish chestnut, pointed with white. The foliage is rounded, smooth. Iittle dentate and of a handsome deep green. Flowers handsome snow white. tinted with deep pink in the sun. This variety still possesses the inestimable quality of resisting spring frosts and one generally secures three crops in four years. The set of fruit is so good that the trees frequentIy bear too many fruits. to the detriment of quality and size; it is not rare for a tree to bear $300 \mathrm{kgms}$. of fruit. M。 Jean Badhe, at Saint Esteve (Pyrenees-Orientales), a heavy producer of apricots, has in a rineyard a tree of 6 meters tall, trunk $35 \mathrm{~cm}$. diameter: in 1925 it produce $300 \mathrm{kgms}$ of fruits, sold at an average of 406 francs per $\mathrm{kgm}$. and in 1936 it produced $345 \mathrm{kgms}$. frory fine fruits. This tree is grafted on Myrobalan and was planted in 190. "In two years 200,000 to 220,000 trees of this variety have been planted in the Departement des Pyreneesmorientales, in addition to 200 or more thousand planted in preceding years. This will make our department the largest producer of rruits in France.

Anonymous note: "May be identical with or close to variety Goletan."

Catalog of Orero, Spain, about 1934. Rouge du Roussillon. - Very hardy variety being much grown in the south of France. Has the characteristic of developing its branches almost vertically, giving the tree a very good form. Great fertility. ripens very early, late May or lst June. Fruit of good size, elongated and flattened. Attractive color, crimson in the sun. Flesh orange, juicy, and much perfuned. Agreeable flavor. Qualities which make this a friit of first quality. Ideal for export. Under list of comeroial varieties. 

Listed by 1 of 26 French catalogs examined $3 / 2 / 42$. Not listed by 1 Swiss and 2 Belgan catalogs examined $3 / 2 / 42$.

\section{Evaluat on Dats}

\section{U. S. Ilant Introduction Garden Chice, Califormia}

P.I. 117200. Rouge de Roussillon. Fruit picked at Chico 6/14/39, Season 6/230 20/39. Drops readily。 Size uniform, rather small, although first piokings tend to rurs smaller, averaging $3.9 \mathrm{~cm}$. in length, $4.2 \mathrm{~cm}$. in diameter and $27.4 \mathrm{gins}$. in weight. Shape rather ablate, halves unequal. Cavity medium depts and widtho regular, moderately arrupt. Suture shallow, distinct. Apess roundisho lightiy depressed. Skin color greenish yellow, a few fruits lightly blushed, pubescence shor, and light, dots inconspicuous, medium thickness and toughress, adherent to flesh. Flesh color greenish yellow, the greenish part usualiy being mext to the skin on the least mature side, juice moderate, texture stringy, tender, melting, flavor mildly sub-acid, quality fair to pooro Stone semi-cling, medium size, roundish oval, plump, blunt, surface pitted, brown.

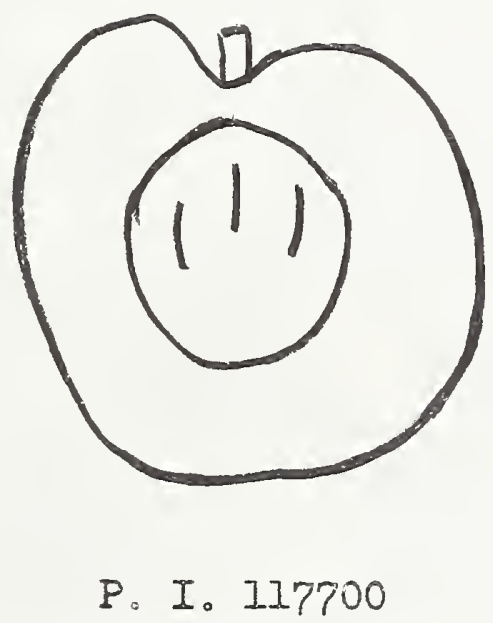

Rouge de Fousinilon

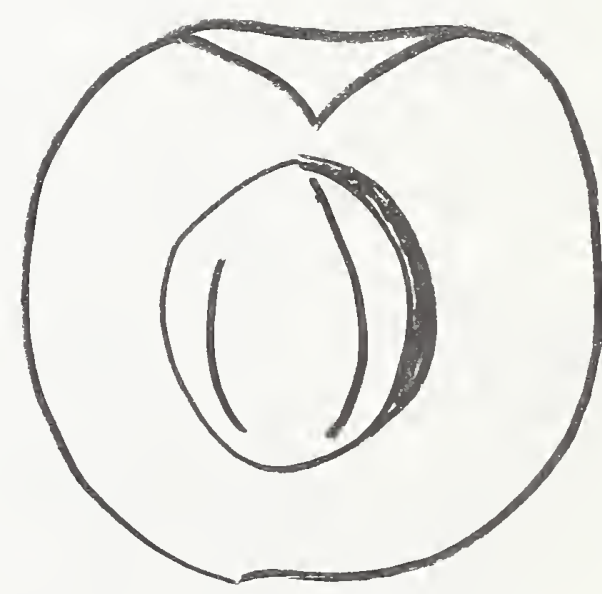

P. I. 96451

Giletass

Only the one year's fruit description at Chico is avazlable. There are suggestions of similarity to Giletan as far as shape is concerned but disferences in flesh and skin color along with size and other internal characteristics raise doubts that they are identical.

No record of time of bloom is avaliable. 
